\title{
SUNRISE, SUNSET: AN EMPIRICAL AND THEORETICAL ASSESSMENT OF DUAL- CLASS STOCK STRUCTURES
}

\begin{abstract}
Andrew William Winden*
A battle is brewing for control of America's most dynamic companies. Entrepreneurs are increasingly seeking protection from interference or dismissal by public investors through the adoption of dual-class stock structures in initial public offerings. Institutional investors are pushing back, demanding that such structures be abandoned or strictly limited through sunset provisions. The actual terms of dual-class stock structures, however, have been remarkably understudied, so the debate between proponents of prohibition and private ordering is often ill-informed. This paper presents the first empirical analysis of the initial, or sunrise, and terminal, or sunset, provisions found in the charters of dual-class companies, with a data set of 139 U.S. public companies. Careful selection of such provisions can satisfy both the desire of entrepreneurs to pursue their idiosyncratic visions for value creation without fear of interference or dismissal and the need of investors for a voice to ensure management accountability. Private law firms representing entrepreneurs in initial public offerings play a critical role in the selection of charter provisions, so the onus is on such firms to ensure that private ordering produces a satisfactory resolution before momentum builds for a regulatory solution to investors' concerns.

I. Introduction 854

II. The Dual-Class Data Set ....................................... 860

III. Sunrise Provisions....................................................... 863

* Fellow, Rock Center for Corporate Governance, Stanford Law School. I am indebted to Joe Grundfest, Jeffrey N. Gordon, George Triantis, Curtis Milhaupt, Evan Epstein, Cathy Hwang and the participants in the 2017 National Business Law Scholars Conference for valuable comments and insights.
\end{abstract}


A. Historical Background to Sunrise Provisions..... 864

B. Voting Rights ............................................... 866

C. Director Elections ............................................... 868

IV. Sunset Provisions ..................................................... 869

A. No Sunset: Eternal Asymmetric Control............ 870

B. Time-Based Sunsets ............................................. 870

C. Dilution Sunsets ................................................ 872

D. Divestment Sunsets........................................... 873

E. Death and Incapacity Sunsets .......................... 875

F. Separation Sunsets ............................................ 878

G. Transfer Sunsets............................................ 880

V. Law Firms and Choices of Sunset Provisions ........... 886

VI. Evaluating Dual-Class Stock Structures ................. 890

A. Entrepreneurs Seek Control to Execute Vision. 890

B. Investors Seek Control to Minimize Value Destruction........................................................... 893

C. The Current Debate: Prohibition vs. Private

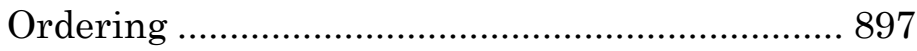

1. Calls for Prohibition ..................................... 898

2. Support for Private Ordering Status Quo .... 902

D. Alternative Standards for Assessing

Dual-Class Stock Structures.............................. 905

VII. Designing Optimal Dual-Class Structures.............. 909

A. Summary …........................................................ 909

B. Sunrise Provisions ............................................. 912

1. Voting Structure ........................................ 912

2. Minority Directors ......................................... 914

C. Sunset Provisions .............................................. 916

1. Time-Based Sunsets ...................................... 916

2. Dilution and Divestment Sunsets ................. 922

3. Death and Incapacity Sunsets...................... 924

4. Separation Sunsets ..................................... 926

5. Transfer Sunsets .......................................... 927

6. Performance Sunsets .................................... 928

7. Fiduciary Sunsets........................................ 929

D. Additional Protections for Dual-Class Investors 930

1. Pro Rata Distribution of Change-of-Control Consideration................................................ 931

2. Compensation for Charter Alterations .......... 932 
3. Selective Power Sharing: Majority of the Minority Votes ............................................... 937

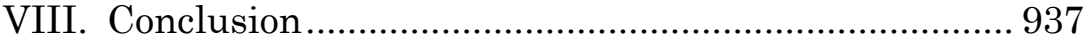

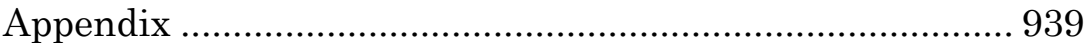

A. Dual-Class Data Set Companies Listed by Dual-Class Adoption or Listing Year ................. 939

B. Time-based, Dilution and Divestment Sunsets.. 943

C. Death and Incapacity Sunsets ........................... 944

D. Transfer Sunsets.............................................. 947

E. Companies Listing Both High- and Low-Vote Shares .............................................................. 950

F. Dual-Class Data Set Companies with Time-Based Sunsets .......................................... 950

G. Dual-Class Data Set Companies with Both Death and Incapacity Sunset Triggers 951

\section{INTRODUCTION}

A modern-day struggle for control of America's most dynamic companies is brewing between entrepreneurs and institutional investors. American entrepreneurs are increasingly using dual-class stock structures, which allow them to retain voting control of their companies even after going public, to obtain protection from interference or dismissal by institutional investors and activist shareholders. The adoption of dual-class share structures among companies conducting initial public offerings ("IPOs") in the United States has rapidly accelerated in recent years, from a few companies per year in the early 2000s to many times that 
number in the last seven years. ${ }^{1}$ The data set $^{2}$ of dual-class companies described in this paper identifies seventy-two companies that adopted a dual-class structure between 2010 and 2017, including some of the largest IPOs and most familiar names in America: Facebook, GoPro, Groupon, LinkedIn, Square, TripAdvisor, Yelp, Zillow, and Zynga. On March 1, 2017, Snap, Inc. ("Snap"), owner of the popular Snapchat app, made headlines by going public -in the most anticipated technology IPO since Facebook's IPO in 2012with a multi-class structure featuring no-vote shares for the new public shareholders. ${ }^{3}$

1 See Alice Gomstyn, Supervoters, Stocks, and Silicon Valley: What Investors Should Know About Dual-Class Voting Structures, THE MoTleY FoOL (Dec. 5, 2015, 9:10 PM), https://www.fool.com/investing/general /2015/12/05/supervoters-stocks-and-silicon-valley-what-investo.aspx

[https://perma.cc/QRM7-ACW6] ("A growing number of U.S. firms have adopted [the dual-class] structure: Between 2013 and late 2015, 98 companies newly listed on U.S. exchanges had dual-class IPOs, compared to 59 between 2010 and 2012, according to data from information provider Dealogic.”); Steven Davidoff Solomon, Shareholders Vote with Their Dollars to Have Less of a Say, N.Y. Times (Nov. 4, 2015), https://www.nytimes.com/2015/11/05/business/dealbook

/shareholders-vote-with-their-dollars-to-have-less-of-a-say.html [https://perma.cc/FSC8-NGGY] ("More than 13.5 percent of the 133 companies listing shares on United States exchanges in 2015 have set up a dual-class structure, according to the data provider Dealogic. That compares with 12 percent last year and just 1 percent in 2005.").

2 This Article is substantially based on a data set created by the author-Andrew William Winden, Dual-Class Data Set (on file with the Columbia Business Law Review)—which is detailed infra Part II. The full data set is on file with the Columbia Business Law Review. The Appendix, infra, includes a full list of the companies included in the data set as well as several tables summarizing various features of the data. In an effort to ensure readability and avoid an excessive use of citations, the Columbia Business Law Review opted not to cite to the data set each time the author refers to it, but only when particularly relevant.

3 See Maureen Farrell, Snap IPO Limits Vote to Founders, WaLL ST. J., Jan. 17, 2017, at B1; Steven Davidoff Solomon, When Snap Goes Public, Some Shareholders' Voting Rights May Disappear, N.Y. Times (Jan. 24, 2017), https://www.nytimes.com/2017/01/24/business/dealbook/when-snapgoes-public-some-shareholders-voting-rights-may-disappear.html [https://perma.cc/W4CU-BSA6]. 
Entrepreneurs are often creative visionaries who continue to develop new ideas and products as their companies grow. The dual-class structure allows them to pursue their vision for creating corporate value without the threat of their ideas being overruled or dismissed by investors who may have less patience for brilliance to manifest than profit. The ghost of Steve Jobs looms large in Silicon Valley, in particular. Founder-entrepreneurs express concern that efforts to recruit and retain the most talented employees and invest in research and development for long-term gains may not be understood or appreciated by markets in the short-term. ${ }^{4}$ On the other hand, investors are concerned that, with dual-class stock structures, especially those involving no-vote shares, expected long-term value will not be realized and corporate assets may be wasted. ${ }^{5}$ In these contexts, dual-class stock structures leave them with no voice to lobby for changes in policies or management and exempting companies from the market for corporate control, which otherwise operates as a check on management.

Alarmed by the increase in dual-class companies, but unable to prevent successful companies from utilizing dualclass structures when they come to market, institutional investors and proxy advisors have mounted a concerted campaign to pressure regulators to prohibit dual-class structures and companies to abandon them. T. Rowe Price announced in March 2016 that it will vote shares held by its mutual funds against the lead independent directors and all nominating committee members of companies with dual-class share structures in future annual meetings. ${ }^{6}$ Institutional

4 See Paresh Dave, Snap's Nonvoting Stock — Everything Sold in the IPO — Is Junk, Investor Says, L.A. TIMES (Mar. 09, 2017, 11:45 AM), https://www.latimes.com/business/technology/la-fi-tn-snap-no-vote-shares20170309-story.html [https://perma.cc/9MEM-BN7F].

5 See id.

6 Lorraine Mirabella, T. Rowe Price Takes Stand Against Stock Structures That Create Unequal Shareholder Rights, BALT. SUn (Mar. 19, 2016), http://www.baltimoresun.com/business/bs-bz-t-rowe-price-opposedual-class-stock-20160319-story.html (on file with the Columbia Business Law Review). 
Shareholder Services (“ISS") announced in November 2016 that for the 2017 proxy season, it would encourage investors to vote against the boards of directors of companies with dualclass share structures unless they have a "reasonable" sunset mechanism, and requested comments from investors as to what constitutes a reasonable sunset mechanism. 7 On January 31, 2017, the Investor Stewardship Group, an organization of influential institutional investors holding an aggregate of $\$ 17$ trillion in assets under management, announced its new corporate governance principles, 8 which require the directors of public companies with dual-class shares to "end or phase out controlling structures at the appropriate time."9

7 Lyuba Goltser, ISS Proposes New 2017 Voting Policies, HaRV. L. ScH. F. ON CORP. Governance \& FIN. REg. (Nov. 2, 2016), https://corpgov.law.harvard.edu/2016/11/02/iss-proposes-new-2017-votingpolicies [https://perma.cc/BJF6-BMST]; US Policy - Unilateral Board Actions - Multi Class Capital Structure at IPO, INSTITUTIONAL SHAREHOLDER SERVS., https://www.issgovernance.com/file/policy/ unilateral-board-actions-multi-class-capital-structure-at-ipo.pdf [https://perma.cc/L5MM-EF6U].

8 Leading Investors Launch Historic Initiative Focused on U.S. Institutional Investor Stewardship and Corporate Governance, BUS. WIRE (Jan. 31, 2017), https://www.businesswire.com/news/home/ 20170131005949/en/Leading-Investors-Launch-Historic-Initiative-

Focused-U.S [https://perma.cc/YVY3-2HXQ]. Led by senior corporate governance practitioners at institutional investor and investment management firms, the initial members of the Investor Stewardship Group were: BlackRock, CalSTRS, Florida State Board of Administration, GIC Private Limited (Singapore's Sovereign Wealth Fund), Legal and General Investment Management, MFS Investment Management, MN Netherlands, PGGM, Royal Bank of Canada Global Asset Management, State Street Global Advisors, TIAA Investments, T. Rowe Price Associates, Inc., ValueAct Capital, Vanguard, Washington State Investment Board, and Wellington Management. Id.

9 The relevant principle states, in its entirety:

Principle 2: Shareholders should be entitled to voting rights in proportion to their economic interest.

2.1 Companies should adopt a one-share, one-vote standard and avoid adopting share structures that create unequal voting rights among their shareholders. 
So the battle lines between entrepreneurs and investors have been drawn and the stakes are high-absent fraud or self-dealing, Delaware corporate law generally upholds the choices of the corporate party or parties with the most votes. 10 There is an urgent need for American lawyers to consider how the respective needs of entrepreneurs and investors can be satisfied to end the impasse. It is difficult to have an informed and productive conversation about how to respond to the dualclass phenomenon, however, without a thorough understanding of the actual terms of dual-class stock structures.11 Even the most lopsided dual-class structureone with no-vote public shares-might be acceptable, for instance, if it ends after a short period of years or once the stock price performance falls below a certain level for a set period of time.

The terms of dual-class stock structures have been remarkably understudied. This paper fills this gap in the literature with a taxonomy and census of the initial, or sunrise, and terminal, or sunset, provisions for 139 U.S. public companies with dual-class stock structures. This review of dual-class terms reveals that there are myriad possibilities for satisfying the needs of both founders and investors in the

2.2 Boards of companies that already have dual or multiple class share structures are expected to review these structures on a regular basis or as company circumstances change, and establish mechanisms to end or phase out controlling structures at the appropriate time, while minimizing costs to shareholders.

Corporate Governance Principles for US Listed Companies, INV. STEWARDSHIP GROUP, https://www.isgframework.org/corporate-governanceprinciples [https://perma.cc/J9DS-ZF43].

10 See, e.g., Mendel v. Carroll, 651 A.2d 297 (Del. Ch. 1994); Sinclair Oil Corp. v. Levien, 280 A.2d 717 (Del. 1971).

11 As Ronald Gilson noted, "To better understand the macroeconomic impact of efficient controlling shareholder systems, we need to better understand the micro-level dynamics of this ownership structure. As the focus of corporate governance scholarship shifts to controlling shareholder systems, we need to think small." Ronald J. Gilson, Controlling Shareholders and Corporate Governance: Complicating the Comparative Taxonomy, 119 HARV. L. REV. 1641, 1678-79 (2006). 
dual-class form. As described in this paper, companies adopting dual-class structures have utilized a variety of sunrise and sunset provisions in the past, and dual-class stock structures have become more investor-friendly over time, particularly in the last decade as use of the structure has proliferated among technology companies. It is also possible to imagine additional charter provisions that could be used to satisfy both the entrepreneurs' need for control and the investors' need for influence. When the existing and possible future options are fully understood and considered, law firms representing companies pursuing initial public offerings can and should design multi-class stock structures that weave together the disparate expectations of entrepreneurs and investors, making resort to regulatory limitation or prohibition unnecessary.

Part II of this paper describes the hand collected data set created to analyze the existing dual-class sunrise and sunset provisions among public companies in the United States. Part III describes the sunrise provisions of dual-class structuressuch as the respective voting rights of the high vote and low vote shares. Part IV describes the sunset provisions of the companies in the data set. Part V explains the influence of law firms acting as issuer's counsel on the design of dual-class structures used in recent IPOs in the United States. Part VI discusses standards for evaluating dual-class stock structures, describing the theoretical background to the positions taken by entrepreneurs and investors. It then suggests alternative standards for evaluating dual-class stock structures based on the fundamental motives of the partiesentrepreneurs seek control in order to pursue their idiosyncratic visions for creating value, 12 while investors seek control for influence, voice, and management accountability in order to minimize diminutions in corporate value through management agency costs. 13 Finally, Part VII discusses optimal dual-class share structures, evaluating the various

12 Zohar Goshen \& Assaf Hamdani, Corporate Control and Idiosyncratic Vision, 125 YALE L.J. 560, 565-66 (2016).

13 Id. at 569, 576-83. 
structures in use today and suggesting possible modifications in light of the standards discussed in Part VI.

\section{THE DUAL-CLASS DATA SET}

Despite the controversy over dual-class stock structures, the actual terms used by such stock structures are remarkably understudied. In order to promote an informed discussion of these structures, I created a hand-collected data set of the sunrise (initial) and sunset (terminal) charter provisions used by public companies adopting dual-class stock structures. To keep the number of companies in the data set to a manageable number, I used slightly different criteria for inclusion of twentieth and twenty-first century corporations. Among companies that went public with dual-class stock structures before 2000, the data set focuses on large- and mid-cap companies (S\&P 500, S\&P 400, and Russell 1000 stocks). This excludes smaller, less dynamic controlled companies that are arguably more like close corporations, and includes most of the market value represented by dual-class companies. 14 Among companies that have gone public since 2000, the data set also includes small-cap (S\&P 600, Russell 2000) and unindexed companies, which are earlier in their corporate lifecycles. Much of the innovation in dual-class stock structures has occurred in the last ten to fifteen years, so it was also important to be more inclusive for more recent years in order to accurately capture the proliferation of creative sunrise and sunset structures.

To identify companies with dual-class stock structures, I started with the list of S\&P 1500 controlled companies created by ISS on behalf of the Investor Responsibility Research Center Institute ("IRRCi"). 15 Most of the companies that

14 The Russell 1000 represents more than ninety percent of the market capitalization of the companies in the Russell 3000, with the Russell 2000 representing only the remaining ten percent. Russell 1000 Index, INVESTOPEDIA,

https://www.investopedia.com/terms/r/russell_1000index.asp [https://perma.cc/LB2Y-RZ9A].

15 Edward Kamonjoh, Institutional S'holder Servs., Controlled Companies in the Standard \& Poor's 1500: A Follow-up Review of 
conducted dual-class IPOs in recent years are not included in the IRRCi study because they are not included in the S\&P 1500. To identify more recent dual-class market entrants, I reviewed the charters of companies with "unequal voting" provisions in the Takeover Defense database of SharkRepellent.net provided by FactSet.16 Many of the companies in the SharkRepellent database were not actually dual-class companies giving founders unequal voting rights, which highlights the need for careful selection of the data set when creating regression analyses of "dual-class" companies or doing other empirical research based on these databases. 17

PERFORMANCE AND RISK 84-90 (2016). A significant number of the controlled companies in the IRRCi S\&P 1500 data set created by ISS were S\&P 600 small-cap companies that went public before the year 2000 and were eliminated from the data set as explained supra text accompanying note 14 .

16 The SharkRepellent.net database, as of December 17, 2017, included 357 companies with unequal voting provisions, 183 of which were Russell 2000 companies, 111 of which were Russell 1000 companies, 38 of which were S\&P 500 companies and 35 of which were S\&P 400 companies. More than half of the companies in the SharkRepellent.net database were Russell 2000 companies that went public before 2000 and were therefore eliminated from review. See FactSet Research Systems, Inc., SHARKREPELLENT.NET, https://www.sharkrepellent.net [https://perma.cc/23GE-LETN].

17 A large number of the companies identified by SharkRepellent.net as having unequal voting rights are not dual-class companies in the traditional sense because the unequal voting provisions were not created to give company insiders greater voting power than their cash-flow rights. Companies have multiple classes of voting or non-voting common stock for a variety of reasons unrelated to enhancing the rights of founders. Some companies identified by the database, such as Aflac, Inc., Carlisle Companies, Inc., Synovus Financial Corp., and The J.M. Smucker Co., employ tenure voting systems, rather than a fixed dual-class system. A significant number of companies, particularly in the financial services industry, have unlisted non-voting shares to permit certain investors to satisfy regulatory limitations on their voting rights in the firm. Others are yieldcos or other subsidiaries whose control shares are held by corporate parents. Still other companies have "supervoting" shares to effectively allow shareholders of Canadian subsidiaries to have a number of votes at the U.S. parent equal to the number of votes they would otherwise have at the subsidiary level. Finally, numerous companies in the unequal voting data base have multiple classes of common equity to facilitate an Up-C IPO structure. In an Up-C IPO, pre-IPO owners retain flow-through tax benefits by retaining their economic interest in an existing partnership or LLC 
Finally, I compared my list with the list published by the Council of Institutional Investors in March 2017 to establish a final data set of the charter terms of 139 dual-class companies. ${ }^{18}$

After identifying companies with multiple classes of disparately voting common shares, I hand-collected information regarding the dual-class sunrise and sunset provisions included in the articles or certificates of incorporation (collectively, "charters") of such companies filed as exhibits in the Security and Exchange Commission's ("SEC's") Electronic Data Gathering, Analysis, and Retrieval ("EDGAR") system in order to create the dual-class data set.19 A full list of the companies I included in the data set, listed by the year in which they went public, or, where known, otherwise adopted a dual-class structure, is included as Appendix A. ${ }^{20}$ Appendix B contains summary tables of sunset

operating entity. Public shareholders are offered shares of a listco corporation which acquires membership interests in the LLC equal to the public ownership interest. Pre-IPO investors get a separate class of equity in the listco which typically gives them listco voting rights equal to their economic interest in the LLC but no economic claim on the corporation. Thus, Up-C IPOs in which founders control the listco are generally more like concentrated ownership structures than dual-class structures. I excluded all of these companies with "unequal" voting rights from the dualclass data set. While I do not have access to the Dealogic database, I suspect the Dealogic statistics regarding the number of dual-class IPOs in recent years cited by the articles listed supra, note 1, inflate the actual number of dual-class IPOs by including some of the same categories of non-dual-class firms with multiple classes of common equity included in the SharkRepellent.net database.

18 The Council of Institutional Investors list of dual-class companies is available on the CII website. Dual-Class Stock, CounCIL OF InsTITUTIONAL INV., https://www.cii.org/dualclass_stock [https://perma.cc/UJN6-F7V2].

19 This includes both companies with high vote and low vote common stock and companies with voting and non-voting common stock, as well as a few companies, such as Alphabet, Discovery Communications and Under Armour, with high vote, low vote, and non-voting common stock.

20 While I generally did not include former dual-class companies that are no longer public, because it is more difficult to identify them and obtain information about their dual-class structures in currently available databases, I did include a few companies that have been acquired in recent 
provisions employed by those companies, and Appendix C contains lists of firms with certain relevant characteristics. The full data set is on file with the Columbia Business Law Review.

As will become immediately apparent upon perusing the list of companies in Appendix A, dual-class adoption in the twentieth century was by no means limited primarily to companies in journalism and media (as has been commonly understood) and twenty-first century adoption has by no means been limited to technology companies, although the adoption of dual-class structures by increasing numbers of technology companies is largely responsible for the rapid increase in the number of dual-class companies in the last seven years.

\section{SUNRISE PROVISIONS}

The initial structural, or sunrise, provisions of a dual-class stock structure focus on the differing rights of multiple classes of common stock, most importantly, the general voting and director election rights. Generally speaking, the other rights of the different classes of common stock, such as the right to receive dividends, are indistinguishable. Many of the companies in the data set also protect low vote shareholders in change of control transactions by giving all classes the same consideration upon a change of control or giving low vote shares a separate vote on such transactions unless the consideration is the same. 21

years for which such information was readily available, such as Cablevision, DreamWorks, Kayak.com and Molex. See infra Appendix A.

21 These dividend and merger equity provisions are consistent with the prediction of Goshen and Hamdani's idiosyncratic vision theory that founders seek control not to extract private benefits of control, but rather to protect their ability to pursue their visions for creating above market returns to be shared ratably with all equity holders, as discussed infra Part V. See generally Goshen \& Hamdani, supra note 12. 


\section{A. Historical Background to Sunrise Provisions}

The current New York Stock Exchange ("NYSE") and Nasdaq rules do not impose any specific requirements for the sunrise or sunset provisions of dual-class structures-they only prohibit the mid-course adoption of classes of equity that dilute the voting power of existing shareholders. 22 While the NYSE generally prohibited dual-class listings from the mid1920 s to the mid-1980s, 23 the American Stock Exchange ("AMEX") and Nasdaq had more flexible policies. ${ }^{24}$ In 1976, the AMEX permitted Wang Laboratories to list with a dualclass structure, subject to certain requirements that became AMEX policy for such listings.25 The "Wang formula," as it was called, included the following requirements:

- Limited voting shares must have the abilityvoting as a class - to elect not less than twenty-five percent of the board of directors.

- The voting ratio may not be greater than 10:1 in favor of the high vote shares.

- No additional stock may be created that would in any way diminish the voting rights of the limited voting shares.

- The high vote shares should lose certain of its attributes if the number of such shares falls below a certain percentage of the total capitalization.

22 Voting Rights, NYSE Listed Company Manual § 313.00 (2018); Voting Rights, Nasdaq Stock Market Equity Rules, § 5640, IM-5640, Voting Rights Policy (2018).

23 Some exceptions were made-for Ford Motor Company, for example. See Stephen M. Bainbridge, The Short Life and Resurrection of SEC Rule 19c-4, 69 WAsh. U. L.Q. 565, 569 (1991); Joel Seligman, Equal Protection in Shareholder Voting Rights: The One Common Share, One Vote Controversy, 54 Geo. WAsh. L. REV. 687, 700 (1986).

24 The AMEX rule stated: "The Exchange will not approve an application for the listing of a non-voting common stock issue. The Exchange may approve the listing of a common stock which has the right to elect only a minority of the board of directors." Seligman, supra note 23, at 691 . Regarding NASDAQ's policies, see Bainbridge, supra note 23, at 575-76.

25 Seligman, supra note 23, at 704. 
- It was strongly recommended that the low vote class have a dividend preference. 26

At least twenty-two other companies followed the Wang formula with initial public offerings on the AMEX and seven more recapitalized into dual-class structures according to the Wang formula. 27 Other companies started recapitalizing with dual-class structures as a takeover defense mechanism.28 Competition among the exchanges ensued and the NYSE and Nasdaq ultimately adopted rules that also permitted dualclass listings, with significantly fewer requirements than those included in the Wang formula. ${ }^{29}$

Efforts to impose structure on dual-class adoptions at the NYSE and Nasdaq in the course of adapting to the AMEX approach ultimately came to no avail. In 1985, the NYSE subcommittee tasked with establishing rules for dual-class listings proposed a rule permitting listed companies to adopt a dual-class share structure as long as the voting differential per share was no more than 10:1 and the rights of the holders of the two classes of common stock were substantially the same except for voting power per share. 30 In 1986, the directors of the NYSE ultimately proposed a rule that did not include the 10:1 voting ratio or similar rights restrictions. ${ }^{31}$

26 Id. at 704 n.90 (citing Letter from Richard Scribner, Exec. Vice President for Legal and Regulatory Affairs of the AMEX to Joel Seligman (Aug. 15, 1985)).

27 Id. at 704-05.

28 See Jeffrey N. Gordon, Ties That Bond: Dual Class Common Stock and the Problem of Shareholder Choice, 76 CALIF. L. REV. 1, 13 (1988); M. Megan Partch, The Creation of a Class of Limited Voting Common Stock and Shareholder Wealth, 18 J. FIN. EcoN. 313, 317, 322 (1987) (describing forty-three firms that adopted dual-class structures between 1962-84, of which thirty-three permitted public shareholders to elect a minority of the members of the board of directors).

29 See supra, note 22.

30 Seligman, supra note 23, at 692.

31 Id. at 693. As of September 30, 1985, ten companies listed on the NYSE had dual-class share structures, despite the NYSE's policy against non-voting shares and dual-class companies. These were Dow Jones, Ford Motor Co., Hershey Foods, General Motors, General Cinema, Fedders, Coastal, American Family, J.M. Smucker and Kaufman and Broad. Id. at 
Also in 1985, Nasdaq proposed a rule, which was never adopted, that would have permitted dual-class share structures only if they were limited to ten years and had a voting rights ratio of $10: 1.32$

While the NYSE and Nasdaq failed to pass rules imposing limitations on dual-class sunrise structures, and AMEX was ultimately required to liberalize its requirements to keep up with them (the AMEX ultimately merged with the NYSE in 2008), the 10:1 ratio included in the Wang formula and considered by the NYSE and Nasdaq clearly became the prevailing norm among companies adopting dual-class structures. ${ }^{33}$ The Wang formula requirement that noncontrolling public shareholders be permitted to elect a minority of the directors was adopted much more sparingly. ${ }^{34}$

\section{B. Voting Rights}

A substantial majority of the firms in the data set have uncomplicated dual-class voting systems in which one class of common stock, held by founders and some or all pre-IPO investors, has a significantly greater number of votes on all matters than the class of common stock that is listed and sold to public investors. More than sixty percent of the companies in the data set had a 10:1 difference in voting rights (generally $10 x$ vs. $1 x$, although a small number of companies originally listed on the AMEX, still have a 1x vs. 1/10thx voting ratio). Eleven companies have a ratio lower than 10:1, while six companies have a ratio greater than 10:1.35

703 n.81. The AMEX had approximately sixty companies with two classes of stock and the NASDAQ had at least 110. Id. at 703.

32 Id. at 692.

33 See infra Section III.B.

34 See infra, Section III.C.

35 Before the collapse of its dual-class structure into a single class structure in November 2016, Groupon had a 150:1 voting ratio. Universal Health Services has a 1000 to 1 voting ratio: the founder, Alan Miller, holds $100 \%$ of the Class C shares that have 100 votes per share, while the publicly listed Class B shares have 1/10 th of a vote per share. Andrew William Winden, Dual-Class Data Set (on file with the Columbia Business Law Review). 
Another straight-forward sunrise voting structure divides common stock between shares that have one vote per share and shares that have no votes per share. Despite the statements of journalists and pundits to the contrary, ${ }^{36}$ the Snap listing and sale of non-voting common stock to public investors was not the first initial public offering of non-voting shares. A number of other companies in a variety of industries have issued non-voting shares. A 1925 offering of non-voting shares by Dodge Brothers, Inc. led the NYSE to effectively ban the issuance of nonvoting stock for sixty years. 37 Eight of the firms in the data set-in a diverse array of industries including education, insurance, investing, and liquorsoffered public investors nonvoting common stock in the 1970s, 80s, and 90s. 38 A few more firms, including Scripps Networks, The New York Times, and The Washington Post, offered investors shares with no votes except in the election of directors.

About thirteen percent of the companies in the data set have more complicated voting structures. Some firms have three or four classes of common stock, each with different voting rights. Others companies, such as Comcast (one third) and Ford (forty percent), give the founder or founding family the right to control a significant minority of the voting rights in the company regardless of equity ownership. Still others limit the power of the high vote shares or the voting rights of the low vote shares to a limited number of voting matters, such as changes of control, executive compensation, and liquidation.

While most dual-class companies list and offer to the public only their low or no vote classes of common stock, fifteen of the

36 See Rob Kalb \& Rob Yates, Snap, Inc. Reportedly to IPO with Unprecedented Non-Voting Shares for Public, HARV. L. ScH. F. ON CORP. GOVERNANCE \& FIN. REG. (Feb. 7, 2017), https://corpgov.law.harvard.edu /2017/02/07/snap-inc-reportedly-to-ipo-with-unprecedented-non-votingshares-for-public/ [https://perma.cc/GJP3-DTC2].

37 Seligman, supra note 23, at 694-99.

38 Snap does appear to be the first technology company to offer public investors nonvoting shares in its IPO. Andrew William Winden, Dual-Class Data Set (on file with the Columbia Business Law Review). 
companies in the data set have listed both their high vote and their low vote classes of common stock, including several that originally listed their shares on the AMEX.39 More recently, several companies have newly listed (or proposed to list) nonvoting common stock after previously listing low vote common shares. 40

\section{Director Elections}

Another significant sunrise provision included in the charters of twenty of the dual-class companies in the data set is the right of public shareholders holding low vote shares to elect a minority of the directors of the company. These provisions generally give the low vote stockholders the right to elect a quarter to a third of the directors. Several of these companies were initially listed on the AMEX and presumably included the director election right pursuant to the Wang formula. ${ }^{41}$ Several companies controlled by either Barry Diller or the Nolan family also adopted this structure. ${ }^{42}$ Nike, which

39 For companies listing both high and low vote shares, see infra Appendix C.

40 Alphabet, Under Armour, and Zillow Holdings have each listed a new class of nonvoting common stock in addition to their existing classes of high and low voting common stock. Facebook and IAC/Interactive proposed to do so but withdrew their proposals following shareholder lawsuits seeking to block the issuances. See Blair Nicholas, Mark Lebovitch \& Brandon Marsh, CalPERS Suit Marks Another Loss for Multiclass Stock Plans, LAW360 (Oct. 10, 2017, 1:49PM), https://www.law360.com/articles/957467 /calpers-suit-marks-another-loss-for-multiclass-stock-plans (on file with the Columbia Business Law Review); Deepa Seetharaman \& Sarah E.

Needleman, Facebook Abandons Plans to Change Share Structure, Avoiding Lawsuit, WALL ST. J. (Sept. 22, 2017, 7:43 P.M.), https://www.wsj.com/articles/facebook-abandons-plans-to-change-sharestructure-avoiding-lawsuit-1506114877 (on file with the Columbia Business Law Review).

41 See supra note 26 and accompanying text.

42 Barry Diller controls IAC/Interactive, Expedia, TripAdvisor, and the Nolan family controls AMC Networks, Cablevision, and The Madison Square Garden Company. See Andrew William Winden, Dual-Class Data Set (on file with the Columbia Business Law Review). 
listed on the New York Stock Exchange in 1980, used this structure, giving Phil Knight the right to elect seventy-five percent of the directors and public investors the right to elect twenty-five percent of the directors, while otherwise adopting a one share, one vote approach to shareholder voting. Molson Coors adopted a similar structure with equal voting other than for directors in 2005.

Most of the companies including a minority right to elect directors in their charters have provisions in their by-laws allowing public shareholders to nominate directors for election at annual meetings of shareholders with advance notice to the company and the board. The by-laws also generally permit a majority of acting directors to nominate directors for election by the minority shareholders. The bylaws do not typically provide for proxy access by the minority shareholders, however, so the ability of minority shareholders to get desired directors elected is dependent upon such shareholders having and using the financial resources necessary to conduct an independent proxy campaign for the directors they nominate pursuant to the advanced notice bylaws or similar director nomination provisions.

\section{SUNSET PROVISIONS}

Sunset provisions require some or all of the high vote shares to automatically convert to low vote shares upon the occurrence of certain events. The companies in the data set employed a wide variety of sunset provisions, including, most saliently: (1) no sunset at all, (2) the passage of a set number of years, typically measured by the anniversary of the listing (time-based or "listing anniversary" sunsets), (3) the dilution of high vote shares or controller ownership of such shares down to a low percentage of the aggregate number of outstanding common stock shares (dilution sunsets), (4) a diminution in the number of high vote shares or the number of high vote shares held by the controller as a percentage of the controller's original ownership (divestment sunsets), (5) the death or incapacity of natural person holders (death or incapacity sunsets), (6) founder separation from employment with the company (separation sunsets), and (7) conversion 
upon transfers of the high vote shares to persons or entities other than permitted transferees (transfer sunsets). Tables detailing the incidence of various sunset provisions among the companies in the dual-class data set are included in Appendix B.

\section{A. No Sunset: Eternal Asymmetric Control}

Among the companies in the data set, sixty-four percent of the companies that went public prior to 2000 and thirty-six percent of the companies that went public after 2000 did not have any sunset provisions in their charters at all. Several more companies have either dilution or divestment sunsets that are so de minimis as to be meaningless, or included transfer sunsets excluding transfers to family members. So, a total of 74 of the 139 companies in the data set, or fifty-three percent, do not have any effective sunset provisions in their charters. As the tables in Appendix B show, however, there is a clear trend toward more companies including more sunset provisions in their charters over time. 43

\section{B. Time-Based Sunsets}

Time-based sunsets require automatic conversion of the high vote stock into low vote stock upon the passage of a certain number of years following the initial public offering of the low vote stock. This is presumably what most institutional investors and proxy advisors are referring to when they insist that dual-class companies must adopt reasonable sunset provisions. Only 25 of the 139 companies included in this dualclass data set adopted such a time-based sunset provision. ${ }^{44}$ The period of time before automatic conversion varies from five to twenty-eight years. Until 2017, seven years had been the most frequently chosen period. As a result of several offerings in 2017 including ten-year time-based sunsets, the

43 While eighty percent of the companies going public before 2000 had no effective sunset, only forty percent of the companies going public after 2000 had no effective sunset.

44 Andrew William Winden, Dual-Class Data Set (on file with the Columbia Business Law Review). 
most frequent period is now ten years. In two cases, the anniversary sunset is dependent upon the extent to which high vote shares have been diluted or divested. 45 Among the companies with time-based sunsets in the dual-class data set, four (Rockwell Automation, Texas Roadhouse, Groupon, and MaxLinear) have experienced an automatic conversion of their high vote shares into low vote shares and reclassification into a single class of common stock. 46

There has been a significant increase in the number of companies adopting time-based sunsets in the last few years, with thirty-five percent of the companies listing from 2010-

45 The Ironwood Pharmaceuticals certificate provides that if the high vote shares constitute less than twenty percent of the authorized and twenty-five percent of the aggregate number of shares of common stock outstanding, the high vote shares will automatically convert on the eighth anniversary of the 2010 listing date. Otherwise, they will convert on the twenty-eighth anniversary. Ironwood Pharm., Inc., Annual Report (Form 10-K) (Mar. 30, 2010), https://www.sec.gov/Archives/edgar/data/1446847/ 000104746911002858/a2202841z10-k.htm [https:/perma.cc/8HK9-FCPM]. RingCentral provides that as long as a high vote shareholder and, other than in the case of a founder, its permitted transferees hold at least fifty percent of the high vote shares held by such holder at the time of the initial public offering, the high vote shares held by such stockholder will not automatically convert pursuant to the otherwise applicable sunset on the seventh-year anniversary of the initial public offering. RingCentral, Inc., Current Report (Form 8-K) (June 3, 2015), https://www.sec.gov/Archives/edgar/data/1384905/000119312515 212122/d935472d8k.htm [https://perma.cc/TS9C-4FEN].

46 The Rockwell Automation high vote shares converted on February 23, 1997. Rockwell Int'l Corp., Annual Report (Form 11-K) (June 30, 1997), https://www.sec.gov/Archives/edgar/data/1024478/0001024478-97-

000009.txt [https://perma.cc/R9N3-7PLC]. The Texas Roadhouse high vote shares converted on September 30, 2009. Texas Roadhouse, Inc., Current Report (Form 8-K) (Oct. 2, 2009), https://www.sec.gov/Archives/edgar/data/ 1289460/000110465909057645/a09-29694_18k.htm [https://perma.cc/QZ76AKVD]. Groupon's high vote shares converted into low vote shares on October 31, 2016. Groupon, Inc., Current Report (Form 8-K) (Oct. 31, 2016), https://www.sec.gov/Archives/edgar/data/1490281/000119312516753614/d2 74158d8k.htm [https://perma.cc/8MXH-4HBQ]. MaxLinear's high vote shares converted into low vote shares on March 29, 2017. MaxLinear, Inc., Current Report (Form 8-K) (Mar. 30, 2017), https://www.sec.gov/Archives/edgar/data/1288469/000119312517102630/d3 20231d8k.htm [https://perma.cc/H24M-KJ2J]. 
2017 adopting such sunsets, as compared to only three percent of the companies in the data set that listed prior to 2010. In 2017 , forty-one percent of the companies adopting dual-class structures included time-based sunsets. While the vast majority of companies with time-based sunsets in the data set are technology companies listed over the last seven years, and the number of companies adopting time-based sunsets has increased significantly compared to prior periods, these sunsets are neither a recent phenomenon nor limited to the tech sector. Among time-based sunset adopters found in the data set are a real estate company, a restaurant chain, and manufacturers, in addition to software companies. For example, Helene Curtis, a cosmetics company, adopted a reviewable five-year time-based sunset in the dual-class structure it adopted in the 1980s. 47

\section{Dilution Sunsets}

A dilution sunset triggers a conversion of the high vote shares to low vote shares when the number of high vote shares declines below a set percentage of the aggregate number of high vote and low vote shares outstanding. This dilution of the high vote shares can occur as a result of a decline in the number of high vote shares through conversion into low vote shares (typically for sale in the public market) or an increase in the number of low vote shares as the latter are used to compensate employees, acquire other companies, or obtain additional capital for investment in the enterprise. 48

Forty-eight of the companies in the data set, eight of which went public prior to 2000 , included a dilution sunset provision in their charters. Among the forty-eight companies with a dilution sunset provision, fifty-four percent of them made dilution below ten percent the trigger for automatic

47 Gordon, supra note 28, at 80.

48 Typically, high vote shares and low vote shares are separate series of common stock and the denominator for purposes of a high vote dilution sunset provision is the "aggregate common stock outstanding." 
conversion. 49 One of the companies included in the data set, Yelp, Inc., collapsed its dual-class structure into a single class of common stock as a result of triggering its ten percent aggregate share number dilution provision in 2016.50

A number of companies in the data set include dilution conversion triggers based on the percentage of high and/or low vote shares owned by a founder or controller (as opposed to the absolute number of high vote shares outstanding). These provisions come in a variety of versions. The most frequent version, employed by eight companies, triggers a conversion if the number of high vote shares (or high and low vote shares, in aggregate) owned by the founder/controller is lower than a specified percentage, varying by company between five percent and twenty-five percent, of the aggregate number of shares of common stock. 51 Two companies established doubletriggers, requiring the founder/controller's ownership of both high and low vote stock to fall below a specified percentage of the total number of such shares of stock.

\section{Divestment Sunsets}

A close cousin of the dilution sunset is the divestment sunset, which focuses on the number of high vote shares issued and outstanding. There are two types of divestment sunsets: (1) a sunset triggered when the number of high vote

49 In other words, conversion occurs automatically when the high vote shares constitute fewer than ten percent of the aggregate number of shares of common stock outstanding (where both high vote and low vote shares are separate series of common stock).

50 Yelp Inc., Current Report (Form 8-K) (Sept. 22, 2016), https://www.sec.gov/Archives/edgar/data/1345016/000120677416007234/ye lp3063374-8k.htm [http://perma.cc/C33P-RFVB]; see also Alfred Lee, Yelp Shows Way in Supervoting Stock Sunset, THE INFO. (Sept. 26, 2016, 7:01 AM), https://www.theinformation.com/articles/yelp-shows-way-insupervoting-stock-sunset [http://perma.cc/Y8JT-8VGP].

51 The eight companies are: Altair Engineering, Inc., Caravana Co., Houlihan Lokey, Inc., Moelis \& Company, SecureWorks Corp., Texas Roadhouse, Inc., Tilly's, Inc., and Virtu Financial, Inc. See Andrew William Winden, Dual-Class Data Set (on file with the Columbia Business Law Review). 
shares outstanding declines below a set number of shares, and (2) a sunset triggered when the founder/controller sells more than a stated percentage of the shares initially held by the founder/controller. Divestment sunsets focus more directly on the actions of the controlling high vote shareholders than dilution sunsets as they are not influenced by the issuance of additional low vote shares. Thus, while a founder/controller may still worry about voting dilution through the issuance of low vote shares over time, she need not worry about collapse of the dual-class structure as long as she doesn't sell down the requisite number of her high vote shares.

The divestment sunset is the fourth most frequently observed sunset provision, utilized by nineteen of the companies in the data set, including eight companies incorporated before 2000.52 The number of high vote shares triggering a conversion varies as a percentage of the authorized and outstanding shares of high vote stock, depending on the company. Apart from Federated Investors, Inc., which provides for non-voting common stock to convert into voting common stock only if there are no voting shares outstanding, 53 the lowest (that is, most difficult to pull) trigger as a percentage of the number of high vote shares outstanding at the time of the filing of the certificate is less than one percent for Forest City Enterprises, Inc.54 The highest trigger is a number equal to $47.5 \%$ of the high vote shares outstanding, for Ford Motor Company.55 Six

52 See infra Appendix B.

53 Federated Inv'rs, Inc., Registration Statement (Form S-4) (Mar. 20, 1998), https://www.sec.gov/Archives/edgar/data/1056288/ 0000950132-98-000240.txt [http://perma.cc/Y29R-VKU6].

54 Forest City Enters., Inc., Quarterly Report (Form 10-Q) (Dec. 9, 2008), https://www.sec.gov/Archives/edgar/data/38067/ 000095015208010076/134747aexv3w1.htm [http://perma.cc/W6RZ-W6SS].

55 Ford Motor Co., Annual Report (Form 10-K) (Mar. 22, 2001), https://www.sec.gov/Archives/edgar/data/37996/0000037

99601000014/0000037996-01-000014-0002.txt [http://perma.cc/EGD8Q7D7]. According to Ford's balance sheet, Ford had seventy-one million shares of Class B common stock issued and outstanding at the time the August 2000 certificate of incorporation went into effect. Ford Motor Co., Quarterly Report (Form 10-Q) (July 31, 2000), 
companies focus on the number of high vote shares as a percentage of the number of such shares owned by the founder/controller at the time of the initial public offering, with percentages varying between zero percent and fifty percent. 56

\section{E. Death and Incapacity Sunsets}

Another form of sunset provides for the automatic conversion of the high vote shares held by a natural person into low vote shares upon the death or incapacity of the shareholder. In some cases, death and incapacity conversion provisions cause the entire dual-class structure to terminate upon the death of the founder of the company. In most cases, death and incapacity conversion provisions provide for conversion of only the shares held by the affected holder (or founder). Even the latter provisions can lead to termination of the structure over time as the limited number of holders of dual-class shares die or become incapacitated. Some death and incapacity conversion provisions contain loopholes, which effectively eviscerate their sunset potential.

Death and incapacity sunset provisions were not a frequent feature of dual-class stock structures until the twenty-first century. Only two out of forty-two, or five percent, of the dual-class data set companies listed in the twentieth century automatically converted the high vote stock upon the death of the holder. The numbers have risen dramatically in the twenty-first century, however, with twenty-two percent of the data set companies listed in the first decade and fiftyseven percent of the companies listing in the second decade including such provisions. ${ }^{57}$ The dramatic increase of death

https://www.sec.gov/Archives/edgar/data/37996/000003799600000076/0000 037996-00-000076-0001.txt [https://perma.cc/N5DN-AGZK].

56 These six companies are: Bandwidth, Inc. (40\%), Fairway Group Holdings Corp. (0\%), Ironwood Pharmaceuticals, Inc. (25\%), Nutanix, Inc. (20\%), RingCentral, Inc. (50\%), and Snap, Inc. (30\%). Andrew William Winden, Dual-Class Data Set (on file with the Columbia Business Law Review).

57 Andrew William Winden, Dual-Class Data Set (on file with the Columbia Business Law Review). 
and incapacity provisions in the last ten years reflects the significant increase in the number of technology companies adopting dual-class structures. Most of the companies that include such provisions are technology companies; many of the dual-class companies that do not include them are not. ${ }^{58}$

As can be seen in the table in Appendix B, like dilution and divestment sunsets, a variety of approaches to death and incapacity sunsets have emerged. Some provisions focus on holders generally, while others focus only on founders. A majority of the companies including death and incapacity provisions in their IPO charters after 2009 included both holders and founders, with conversion of the shares held by a natural person occurring immediately upon the death of a holder other than a founder, and nine months after the death of a founder (sometimes referred to as a "Key Holder"). 59 Eight companies in the data set, including four companies listed in 2017 , included a separate sunset providing for collapse of the entire dual-class structure upon the death of the founder. 60

$58 I d$.

59 Some companies have slight variations on this provision. Alphabet, for example, states that the high vote shares held by a founder will automatically convert to low vote shares upon the death of the founder unless previously transferred to another founder, in which case they will convert nine months after the death of the transferring founder. Alphabet Inc., Current Report (Form 8-K) (Oct. 2, 2015), https://www.sec.gov/Archives/edgar/data/1652044/000119312515336577/d8 2837dex31.htm [http://perma.cc/75YQ-P3Y9]. The Workday charter states that the high vote shares convert nine months after the death of the last founder to die. Workday, Inc., Quarterly Report (Form 10-Q) (Dec. 7, 2012), https:/www.sec.gov/Archives/edgar/data/1327811/000119312512495545/d4 11267dex31.htm [http://perma.cc/9425-872E].

60 These are: Altair Engineering, Inc. (IPO 2017), Blue Apron Holdings, Inc. (IPO 2017), CarGurus, Inc. (IPO 2017), Hamilton Lane, Inc. (IPO 2017), Moelis \& Company (IPO 2014), NCI, Inc. (IPO 2005), Re/Max Holdings, Inc. (IPO 2013), and Tilly's Inc. (IPO 2012). Facebook proposed to include a charter provision collapsing its dual-class stock structure three years after the death of Mark Zuckerberg in connection with introducing non-voting Class C shares. Facebook, Inc., Proxy Statement (Schedule 14A) (June 2, 2016), https://www.sec.gov/Archives/edgar/data/1326801/0001 32680116000074/facebook2016definitiveprox.htm [https://perma.cc/D5R8A9TF]. Since its listing, Facebook has had no death or incapacity sunset provision. Following a shareholder lawsuit challenging the issuance of the 
Several of the companies include both incapacity and death as a trigger for the conversion of the high vote shares held by the affected person.61 While some of the charters refer to "disability" rather than "incapacity," disability is typically defined for purposes of the provision by reference to legal incapacity, so incapacity is used here to avoid confusion or misperception.

Death and incapacity conversion provisions can only be effective as a sunset provision, however, if they cover not only the directly held shares of the relevant individual, but also shares the decedent previously transferred to permitted transferees (such as trusts, retirement accounts, and other legal entities for estate planning purposes or otherwise). Among companies that went public after 2009, a majority of the holder death and incapacity provisions, and most of the founder death and incapacity provisions, applied the automatic conversion to shares held by permitted transferees and to shares held directly by the individual. 62

A number of other variations on the death and incapacity conversion provision can defeat the sunset effect of the provision. The charters of some companies state that the high vote shares convert upon death, unless the shares are transferred prior to death, and in some cases only if transferred to another high vote shareholder.63 The charter of

Class C shares, Facebook rescinded the proposal to amend its charter. Seetharaman \& Needleman, supra, note 40.

61 See infra Appendix C.

62 In the case of Zynga, the natural person death and incapacity provision includes shares held by permitted transferees, but the founder death and incapacity provision applying to Mark Pincus does not-shares held by his permitted transferees will not automatically convert upon his death or incapacity. Zynga, Inc., Current Report (Form 8-K) (June 13, 2014), https:/www.sec.gov/Archives/edgar/data/1439404/000119312514236407/d7 42303dex31.htm [http://perma.cc/RJ8V-MEUJ].

63 AppFolio, Inc., Quarterly Report (Form 10-Q) (Aug. 6, 2015), https://www.sec.gov/Archives/edgar/data/1433195/000143319515000003/ex hibit3163015.htm [http://perma.cc/T68H-WHBV] (allowing conversion upon death nine months after death unless transferred); Castlight Health, Inc., Quarterly Report (Form 10-Q) (May 12, 2014), https://www.sec.gov/Archives/edgar/data/1433714/000143371414000012/ex hibit31restatedcertifica.htm [http://perma.cc/AHY3-95T6] (granting 
one company applies the death conversion provision only to high vote shares acquired post-IPO, meaning it doesn't apply to the founder and fund holders who control the company. 64

\section{F. Separation Sunsets}

Three of the firms in the survey have included provisions in their charters for conversion of high vote stock if the founder of the company is no longer managing the company. These provisions are separation sunsets.

Among the companies in the data set, Moelis \& Co. broke new ground when, in connection with its 2014 IPO, it included a provision in its charter stating that its high vote shares would be entitled to ten votes per share only if founder, CEO, and controlling stockholder Kenneth Moelis "has not had his employment agreement terminated in accordance with its terms because of a breach of his covenant to devote his primary business time and effort to the business and affairs of the Corporation and its subsidiaries or because he suffered an Incapacity[.]"65

The Moelis \& Co. high vote shares would also lose their additional votes if Kenneth Moelis were ever "convicted of a

automatic conversion unless previously transferred); Ironwood Pharm,,

Inc., Annual Report (Form 10-K) (Mar. 30, 2010), https:/www.sec.gov/Archives/edgar/data/1446847/000104746910002966/a2 197484zex-3_1.htm [http://perma.cc/F8ES-4VT4] (granting automatic conversion unless previously transferred); RingCentral, Inc., Current
Report
(Form
$8-\mathrm{K})$
(June

https://www.sec.gov/Archives/edgar/data/1384905/000119312515212122/d9 35472dex31.htm [http://perma.cc/HCJ7-H6RH ] (excepting conversion upon death if transferred to another high vote shareholder); Workiva, Inc., Current Report (Form 8-K) (Dec. 16, 2014), https://www.sec.gov/Archives/edgar/data/1445305/000144530514005577/w orkiva8-kexhibit31.htm [http://perma.cc/9UAA-L2DH ] (granting automatic conversion unless previously transferred).

64 Inovalon, Inc., Amendment No. 4 to Form S-1 (Form S-1/A) (Feb. 6, 2015), https://www.sec.gov/Archives/edgar/data/1619954/00010474691500 0652/a2222935zex-3_1.htm [http://perma.cc/7AXD-FD4K].

65 Moelis \& Co., Current Report (Form 8-K) (Apr. 22, 2014), https://www.sec.gov/Archives/edgar/data/1596967/000110465914029215/a1 4-10912_1ex3d1.htm [https://perma.cc/VM49-LSY8]. 
criminal violation of a material U.S. federal or state securities law that constitutes a felony or a felony involving moral turpitude ..." 66 This is the only dual-class sunset provision in the data set that provides for a sunset of the dual-class structure upon a felony conviction of the founder/CEO/controlling stockholder. In the case of Moelis, this sunset is an appropriate complement to the founder employment termination provision because the laws and regulations applying to the executives of financial institutions taking custody of client funds make it difficult for persons who have been convicted of a felony involving moral turpitude to serve as executives of such institutions. 67

CarGurus, Inc. and Hamilton Lane, Inc., both of which listed in 2017, included provisions in their charters collapsing the dual-class structure when the founder(s) voluntarily terminate all employment and director positions with the company-in other words, when they are no longer directly involved in the management of the company. 68

In connection with introducing non-voting Class $\mathrm{C}$ common stock in 2016, Facebook proposed amendments to the dualclass sunset provisions in its charter that would convert its high vote Class B common stock into low vote Class A common stock upon the termination for cause or resignation of Mark

66 Id.

67 Convicted felons are often prohibited from working in certain industries under either federal or state law. Commonly prohibited industries include banking, insurance, health care, and real estate. In the financial sector, prohibitions typically extend to persons convicted of crimes involving dishonesty and breaches of trust. For banks and affiliates of insured banks, see Federal Deposit Insurance Act, 12 U.S.C. $\S \S 1818(e)(1)$, (g)(1)(C), 1829(a) (2012). For credit unions, see Federal Credit Union Act, § 205(d), 12 U.S.C. $§ 1785$ (d)(1) (2012). For investment advisors, see Investment Advisors Act of 1940, 15 U.S.C. $\S \S 80 b-3(e)$, (f) (2012). For broker-dealers, see Securities Exchange Act of 1934, 15 U.S.C. $\S \S$ $780(\mathrm{~b})(4)(\mathrm{B}),(\mathrm{b})(6)(\mathrm{A})(2012)$.

68 Cargurus, Inc., Current Report (Form 8-K) (Oct. 16, 2017), https://www.sec.gov/Archives/edgar/data/1494259/0001104659170623 78/a17-24010_1ex3d1.htm [https://perma.cc/7YUF-XZDL]; Hamilton Lane, Inc., Current Report (Form 8-K) (Mar. 10, 2017), https://www.sec.gov/Archives/edgar/data/1433642/000143364217000035/hl exhibit31.htm [https://perma.cc/CQU8-Z7HU]. 
Zuckerberg-its founder, CEO, and controlling stockholderas CEO, board chairman or another "Approved Executive Officer" position.69 Following a shareholder lawsuit challenging the charter amendments, Facebook withdrew the proposal on the eve of evidentiary hearings in 2017 , so the death and separation sunsets included in the proposal have not been incorporated into Facebook's charter.70

\section{G. Transfer Sunsets}

In the twentieth century, free transferability of high vote shares in dual-class companies was the norm. ${ }^{71}$ Thirty of the forty-four companies in the data set that listed their shares in the twentieth century permit free transferability of their high vote stock. Another ten companies permitted transfers only to members of the founding family. Two companies included an outright prohibition on transfers of high vote stock, making any purported transfer a cause for automatic conversion into low vote stock. 72

The listing of Google, Inc. in 2004 appears to have caused a sea change in the free transferability of high vote shares. Google included significant restrictions on the transfer of high vote shares, including a prohibition barring its founders from

69 For purposes of the "termination for cause" provision, cause was defined as a variety of deliberate or willful acts of misfeasance that are "materially and demonstrably injurious to the corporation," though not conviction of a felony. No such act was to be considered deliberate or willful "unless it is done by the Founder in bad faith and without reasonable belief that the Founder's action or inaction was in the best interests of the corporation." Furthermore, the founder/CEO/controlling stockholder could not be terminated for cause without sixty days' notice and an opportunity to be heard by the independent directors of the board. Facebook, Inc., Proxy Statement (Schedule 14A) (June 2, 2016), https://www.sec.gov/Archives/edgar/data/1326801/000132680116000074/fa cebook2016definitiveprox.htm [https://perma.cc/X87H-BB46].

70 Seetharaman \& Needleman, supra note 40.

71 For a list of the companies in the survey by date of listing, see infra Appendix A.

72 See, e.g., Universal Health Serv., Inc., Quarterly Report (Form 10-Q) (Aug. 12, 1997), https://www.sec.gov/Archives/edgar/data/352915/ 0000893220-97-001362.txt [https://perma.cc/4FVW-DAU7]. 
transferring their shares to family members. Only fourteen of the eighty-four companies in the data set that listed after Google permitted free transferability of their high vote shares. That is a remarkable change from the thirty of fifty companies in the survey listing prior to Google that permitted free transferability of their shares. The shift is even more pronounced when one considers the fact that most of the fourteen firms permitting free transferability after Google either publicly list the high vote stock 73 or were spun out of or formed from dual-class companies that permit free transferability themselves. 74

Because charter provisions providing for the conversion of high vote shares into low vote shares upon transfer can lead to a change in control of a dual-class company, if not the collapse of the dual-class structure in its entirety, they are appropriately considered sunset provisions and can be referred to as transfer sunsets. As most U.S. dual-class public companies have listed only their low vote stock, holders of high vote stock are typically permitted to voluntarily convert their high vote stock to low vote stock at any time to obtain liquidity. They may, however, prefer to transfer their high vote stock directly. If, over time, all of the high vote stock is transferred and converted upon transfer, the company will gradually convert to a single class capital structure. Even in the more likely scenario that some, but not all, of the high vote stock is transferred and converted, as high vote stockholders seek liquidity in the public markets, founders or controlling stockholders can lose control of a company over time-

73 For example, Discovery Communications, Inc. (listed in 2008) did this. Andrew William Winden, Dual-Class Data Set (on file with the Columbia Business Law Review).

74 The following list includes such companies. The information in parenthesis that follows notes the year and company from which the company was spun out or formed from. AMC Networks, Inc. (2011Cablevision), Expedia, Inc. (2005-IAC/InterActiveCorp), Molson Coors (2005-Coors), News Corporation (2013-Twenty-First Century Fox), Scripps Networks Interactive, Inc. (2008-E.W. Scripps Company), TripAdvisor, Inc. (2011-Expedia), Twenty-First Century Fox, Inc., the successor to News Corporation (2004 as Delaware re-incorporation of The News Corporation Limited of Australia), and Viacom, Inc. (2005-CBS Corporation). Id. 
particularly if the company also has a dilution sunset provision. 75 Hence, charter provisions that call for conversion of high vote shares upon transfer can lead to an end, or sunset, of the control of the company by a particular stockholder. Charters with strict transfer restraints and provisions for automatic conversion upon the death of natural person holders of high vote stock and their permitted transfereesdiscussed supra Section III.E.- effectively limit control to the lifetime of the founder.

Charter provisions that provide for conversion upon transfer of high vote shares typically include a number of exceptions. The exceptions have been narrowing over time, making many of the more recent transfer conversion provisions more effective as a sunset than earlier ones.

Exceptions that effectively defeat the sunset-forcing potential of the transfer conversion provisions include exceptions for transfers to family members, transfers from one founder to another, transfers to specific stockholders, transfers to other current high vote stockholders, transfers to controlled entities, and transfers from stockholders that are corporations, LLCs, or partnerships to their shareholders, members, or partners, respectively.

Transfer conversion provisions exempting transfers to controlling family members, trusts, and other vehicles for the benefit of the original stockholder and such holder's family members do not act as an effective sunset mechanism. Family exemptions promote the aggregation and extension of control to the controller and the controller's descendants, discouraging family members from breaking ranks and selling control shares to outsiders, for example. As noted above, to the extent transfer conversion provisions were included at all by dual-class companies listing in the twentieth century, they typically exempted transfers to family members and related vehicles, retaining control of the company in the family indefinitely. Tyson Foods, Inc., which listed in 1978, and the Ralph Lauren Corporation, which listed in 1997, are among

75 This is what happened in the case of Yelp, Inc. See Lee, supra note 50 . 
those twentieth century companies that included transfer conversion sunsets with exceptions for family transfers. ${ }^{76}$ Three of the companies that went public since 2000 permit transfers only to family members, 77 while a slightly larger number of post-2000 companies include transfer sunsets with exceptions for transfers to founders' and other high vote stockholders' family members. 78

Transfer conversion provisions which exempt founder-tofounder transfers similarly retain control in the founding group, even if one founder decides to divest and diversify. Six of the companies in the survey, including Alphabet, Inc. (as successor to Google, Inc.) include such founder-to-founder exceptions to their transfer conversion provisions, sometimes referring to the founders as "Key Holders."79

In a similar vein, some transfer conversion provisions exempt transfers to specific stockholders, typically controlling corporate stockholders. 80 A broader version of this provision permits transfer as long as transfer is made to another existing high vote stockholder. Three of the companies in the survey included such a provision, one limiting it to high vote stockholders owning at least one percent of the aggregate number of shares of high vote stock. 81

76 Andrew William Winden, Dual-Class Data Set (on file with the Columbia Business Law Review).

77 These are: Coty, Inc., Dick's Sporting Goods, Inc., and Virtu Financial, Inc. Andrew William Winden, Dual-Class Data Set (on file with the Columbia Business Law Review).

78 These include: Castlight Health, Inc., Duluth Holdings, Facebook, Inc., Fitbit, Inc., Globus Medical, Inc., GoPro, Inc., Ironwood Pharmaceuticals, Inc., Phibro Animal Health Corp., Pure Storage, Inc., Tableau Software, Inc., Twilio, Inc., and zulily, Inc. Id.

79 The six companies are: Alphabet, Inc., Apptio, Inc., Box, Inc., Workday, Inc., Zillow Group, Inc., and zulily, Inc. Id.

80 The following lists examples of companies that have such provisions, along with the company's controlling corporate stockholder in parenthesis: Coty, Inc. (Berkshire), Fairway Group Holdings Corp. (Sterling Advisors), First Data Corp. (KKR), Houlihan Lokey, Inc. (Orix), and SecureWorks Corp. (Denali Entities [Dell]). Id.

81 Fairway Group, Groupon, and Inovalon exempt transfers to other Class B Stockholders. Appfolio, Inc. exempts transfers to registered holders of at least one percent of the total number of high votes shares. Id. 
Some of the companies have clauses that exempt transfers to entities controlled by the high vote stockholder, which permits high vote stockholders to effectively share the voting rights with one or more third parties who also have interests in the entity. Several companies include a broader provision that permits transfers to affiliates or entities that are controlling, controlled by, or under common control with the high vote stockholder. A narrower version of this provision that makes it more challenging to transfer the voting power requires that the high vote stockholder exclusively control the entity. Five of the companies in the survey included references to exclusive ownership. A further refined version of the provision, which seems to be the most prevalent version among more recently listed dual-class companies, requires the high vote stockholder to retain dispositive and voting power over the shares that are transferred to a different legal entity (whether the economic rights in the entity are owned and controlled by the high vote stockholder or not). This latter provision makes it more difficult to pass along the high vote shares through an estate, as the argument could be made that the entity is no longer a permitted transferee after the high vote stockholder dies and is no longer able to exercise voting or dispositive power. This presumption that shares transferred with retention of voting and dispositive power by the transferor convert upon the death of the transferor can be and sometimes is made explicit in the death and incapacity sunset provisions in the charter, as discussed supra, Section III. E.

The requirement for retention of voting and dispositive power was introduced by Google at the time of its listing in 2004. The Google provision established a fairly strict approach to conversion upon transfer, with few exceptions, which were designed to limit, as much as possible, possession of control to the founders and high vote stockholders holding shares at the time of the initial public offering. 82 The Google provision does not permit transfers to family members, or to affiliates, and

82 Google, Inc., Amendment No. 5 to Registration Statement (Form S1/A) (Aug. 9, 2004), https://www.sec.gov/Archives/edgar/data/ 1288776/000119312504135503/ds1a.htm [https://perma.cc/7K8Q-TBQS]. 
prohibits transfers to trusts, individual retirement accounts ("IRAs"), and other legal entities such as partnerships and corporations absent ongoing exclusive control over the voting and disposition of the high vote shares by the original high vote stockholder/founder. ${ }^{83}$ The Google provision also states that the high vote shares transferred to a trust without conversion may not involve the payment of cash, securities, property, or other consideration to the transferor. ${ }^{84}$ The Google provision does, however, provide an exemption for transfers of high vote shares by partnerships and limited liability companies, the kinds of entities typically used by venture capital investors, to their partners or members, respectively, pro rata, if the partnership or LLC held five percent or more of the high vote shares at the time of the initial public offering. ${ }^{85}$

The Facebook listing in 2012 took transfer conversion sunset provisions in a more liberal direction again, reintroducing provisions for dynastic control, including permitting transfers to family members without conversion, and permitting transfers to charitable organizations. 86 The provision also stated that permitted transferees do not lose their status as permitted transferees by virtue of the death of the transferor, which perpetuates control beyond the death of the founder or other high vote stockholders, in direct contrast to the Google provisions. 87 Also, the Facebook approach

$83 I d$.

$84 I d$.

85 Id.

86 Facebook, Inc., Quarterly Report (Form 10-Q) (July 31, 2012), exhibit 3.1, https://www.sec.gov/Archives/edgar/data/1326801/00011931251232 5997/d371464dex31.htm [https://perma.cc/V4NR-HQYR].

87 This provision is no longer effective under the amendments proposed to Facebook's charter in connection with its creation of no vote Class C common stock since all Facebook high vote Class B stock would convert to low vote Class A stock upon the third anniversary of the death or incapacity of Mr. Zuckerberg. Facebook, Inc., Proxy Statement (Schedule 14A) (June 2, 2016), https://www.sec.gov/Archives/edgar/data/1326801/0001 32680116000074/facebook2016definitiveprox.htm [https://perma.cc/D5R8A9TF]. 
includes a significant loophole permitting third parties to obtain control over high vote stock by making it easier to transfer high vote stock to trusts for the benefit of the holder, family members, or others, by dropping the requirement that the transferor must retain voting and dispositive control over the high vote shares held in the trust.

On the other hand, the Facebook approach, which utilizes a defined term, "Permitted Entity", is more restrictive than the Google approach with respect to transfers to other legal entities. The Facebook approach limits the ability of third parties to benefit from full or partial ownership of an entity receiving a transfer of high vote shares by providing that transfers can only be made to corporations, partnerships, and other entities owned exclusively by the transferor, rather than taking the Google approach of insisting that the transferor retain exclusive voting and dispositive control of the high vote shares transferred to such an entity (the economic interests in which might be owned entirely by third parties).

\section{LAW FIRMS AND CHOICES OF SUNSET PROVISIONS}

Prior studies have shown that law firms matter-that is, different law firms choose different terms in preparing the charter documents for clients pursuing an initial public offering. 88 Investment bankers also play an advisory role in the choice of charter provisions, such as dual-class sunrise and sunset provisions, that can affect the pricing of an initial

88 John C. Coates IV, Explaining Variation in Takeover Defenses: Blame the Lawyers, 89 CALIF. L. REV. 1301, 1304 (2001) (finding that Silicon Valley firms were less likely than their New York counterparts to include antitakeover provisions in IPO charters in 1991-92, but were just as likely to include such terms by 1998-99); Robert Daines, The Incorporation Choices of IPO Firms, 77 N.Y.U. L. REV. 1559, 1595 (2002) (finding that companies undergoing an IPO are more likely to be incorporated in Delaware than in their home state when advised by national as opposed to local counsel); Roberta Romano \& Sarath Sanga, The Private Ordering Solution to Multiforum Shareholder Litigation, J. EMPIRICAL L. STUD. 31, 31 (2017) (finding that the adoption of exclusive forum selection provisions in charters and by-laws from 2007-14 was driven by law firms). 
public offering. This dual-class data set similarly suggests that lawyers and bankers play an important role in the choice of charter provisions adopted in an IPO. In dual-class share structures, these parties are particularly relevant to the nature of the sunset provisions chosen.

Wilson Sonsini Goodrich \& Rosati ("WSGR") served as issuer's counsel to Google in connection with its IPO, and has also represented several other companies that have adopted dual-class share structures. ${ }^{89}$ The Google dual-class structure broke new ground with fairly strict transfer sunsets and death and incapacity sunsets for the shares held by its founders, interrupting the inter-generational transfer of control. Most of WSGR's clients have adopted fairly consistent sunrise and sunset provisions in line with the Google precedent. The transfer sunset and death and incapacity sunset provisions were made more restrictive by LinkedIn in 2011, which added the term "for tax or estate planning purposes" to limit the instances in which a high vote stockholder could transfer high vote shares to trusts, IRAs and other entities, and included shares held by permitted transferees of high vote holders in the death and incapacity conversion trigger.90 Most of the companies that adopted the Google model after 2011 included these phrases.91 Later adopters also typically dropped the exemptions for transfers by venture funds structured as partnerships or LLCs. ${ }^{92}$

89 These include Apptio, Box, Dolby Laboratories, LinkedIn, MaxLinear, Mindbody, MuleSoft, Nutanix, RingCentral and Square. Andrew William Winden, Dual-Class Data Set (on File with the Columbia Business Law Review).

90 LinkedIn Corp., Amended and Restated Certificate of Incorporation, Registration Statement (Form S-1/A) (Mar. 11, 2011), https://www.sec.gov/Archives/edgar/data/1271024/000119312511064249/de x32.htm [https://perma.cc/Q2EM-NNL2].

91 This includes Apptio, Box, MINDBODY, RingCentral and Square, but not MaxLinear and Nutanix, which permit transfers to family members, and Dolby Laboratories, which has no sunsets at all. Andrew William Winden, Dual-Class Data Set (on file with the Columbia Business Law Review).

92 Id. 
A number of the companies that have gone public after Facebook have included provisions mimicking the Facebook provision. Facebook and a number of the companies adopting its approach (or their investment bankers) were represented by Fenwick \& West in connection with their initial public offerings. 93 Some of the companies that followed the Facebook approach made their transfer conversion provisions more strict by importing the Google requirement that the transferor retain sole dispositive power and exclusive voting control in their definitions of "Permitted Entity" and "Permitted Trust."94 The Cooley law firm ("Cooley") appeared to begin with the WSGR approach 95 but moved to the Fenwick approach 96 over time.

Cooley, Fenwick \& West, and WSGR are all based in Silicon Valley. The incidence of time-based sunsets, death and incapacity sunsets, and transfer sunsets prohibiting transfers to family members declines significantly among both technology and non-technology companies represented by law firms that are not based in Silicon Valley. Some of those firms are regional, and some of their clients are incorporated in jurisdictions outside Delaware, but many of the firms adopting more founder and dynasty-friendly dual-class charters are national firms. 97

93 Castlight, Fitbit, GoPro, and Workday were all represented by Fenwick \& West. With the exception of Workday, which listed only a few months after Facebook, these companies follow Facebook's original charter, permitting transfers to family members and declining to include a death and incapacity sunset. $I d$.

94 These companies include Pure Storage, Tableau, and zulily, which were all clients of Cooley, however, and not Fenwick \& West. Appfolio also incorporated this limitation into its definition of "Trust". Id.

95 Examples include Yelp and zulily. Id.

96 Examples include Pure Storage and Tableau Software. Id.

97 Consider, for example, Globus Medical (Drinker, Biddle), Inovalon (Morrison \& Foerster), Ironwood Pharmaceuticals (Ropes \& Gray), Phibro Animal (Kirkland \& Ellis), Reata Pharmaceuticals (Vinson \& Elkins), RMR Group (Skadden), Scripps Networks Interactive (Baker \& Hostetler), Swift Transportation (Skadden; Scudder Law Firm), Tilly's (Latham \& Watkins), Trade Desk (Latham \& Watkins), and Workiva (Drinker, Biddle). Other firms have chosen to follow the WSGR model include: Groupon (Winston \& 
It is clear that issuer's counsel has more impact on some matters than they do on others. There is greater variance among the clients of each of WSGR, Fenwick \& West, and Cooley with respect to matters such as the use of time-based, dilution, and divestment sunsets. Accordingly, it appears that such matters receive significantly greater input from clientseither founders or their boards of directors, which typically includes venture capital investors - than death and incapacity sunsets and transfer sunsets, which tend to follow the model utilized by the firm more consistently. 98

Bankers also provide guidance to founders as they consider dual-class stock structures, based on bankers' experience from prior deals regarding the effects of different provisions on the pricing of deals. It appears that one of the most important common denominators among the early adopters of timebased sunset provisions in recent years were Morgan Stanley (as a leading underwriter) and Davis, Polk \& Wardwell (as counsel to the underwriters). Of the first six initial public offerings that included a time-based sunset provision after such provisions began to be adopted with regularity in 2010, Morgan Stanley was involved in five and Davis Polk \& Wardwell was involved in four.99

Strawn), Kayak (Bingham McCutchen), Twilio (Goodwin), Veeva Systems (Gunderson), Wayfair (Latham \& Watkins), and Zillow (Perkins Coie). Id.

98 Five of WSGR's ten clients in the data set included time-based sunsets, whereas two of five Fenwick clients did so, and two of five Cooley clients did so. $I d$.

99 Morgan Stanley was "lead left", or the leading bank, in offerings by: MaxLinear (2010), Groupon (2011), Kayak Software (2012), and Workday (2012). Morgan Stanley was a joint book-running manager with an equal allocation to the lead left, J.P. Morgan, in the initial public offering of Ironwood Pharmaceuticals, the first company in recent years to go public with a time-based sunset provision, in February of 2010. Morgan Stanley was not involved in the initial public offering of Yelp (2012). Davis Polk \& Wardwell represented the underwriters in the IPOs of Ironwood Pharmaceuticals, MaxLinear, Kayak Software, and Yelp. Id. 


\section{EVALUATING DUAL-CLASS STOCK STRUCTURES}

Developing such an understanding of existing dual-class sunrise and sunset provisions allows for informed discussion of the burgeoning competition for control between entrepreneurs and institutional investors. To evaluate dualclass stock structures and establish criteria for considering different options for designing them, it is important, as an initial matter, to understand why they are sought by entrepreneurs and fought by investors.

\section{A. Entrepreneurs Seek Control to Execute Vision}

Entrepreneurs seek voting control of their companies postIPO in order to retain the freedom to pursue their unique visions for creating corporate value-their idiosyncratic visions-without worry that public shareholders will challenge their decisions or dismiss them from their positions as managers or directors of the firms they have built from the ground up.100 Goshen and Hamdani explain that this is a natural result of asymmetrical information and differences of opinion between founders and public investors.101 Because entrepreneurs naturally have information about their businesses that they are not able to make public for competitive reasons, and because they may have different opinions from public investors about the best ways to create value through their businesses, they worry that shareholders will prevent them from realizing their business plans. Control enables entrepreneurs to capture the value they attach to the execution of their idiosyncratic vision, which they believe will maximize corporate value and produce above-market returns

100 See, Goshen \& Hamdani, supra note 12, at 590.

101 See generally id. 
in the long term.102 Goshen and Hamdani's theory is supported by the words of entrepreneurs themselves. 103

102 While capturing the value attached to the execution of an idea is essentially a non-pecuniary private benefit of control, Goshen and Hamdani argue that entrepreneurs also seek control in order to increase the size of the corporate pie-to increase pecuniary benefits generally available to all shareholders on a pro rata basis. They are not attempting to dictate the pie's distribution (through the consumption of pecuniary private benefits of control, such as engaging in transactions that increase the size of the firm in order to justify higher compensation for management). Id. at 576. Instead of assuming that controlling shareholders are expropriators who are motivated by a desire to consume private benefits at the expense of minority shareholders, they assert that many controlling owners are instead motivated primarily by a desire to purse their idiosyncratic visions that they believe will increase the value of their firms to the benefit of all shareholders. Id.

103 Noam Wasserman, The Founder's Dilemma, HaRv. Bus. Rev., Feb. 2008, at 102, 104 (noting that several entrepreneurs have told Wasserman "I'm the one with the vision and the desire to build a great company. I have to be the one running it"); Lee, supra note 50 (quoting Sunny Gupta, CEO and co-founder of Apptio, justifying a dual-class structure on the basis that the founders are the ones who "built the company from the ground up"). In Google's 2004 Registration Statement, co-founder Larry Page emphasized the need for autonomy to pursue long-term projects that could create significant value for shareholders:

In the transition to public ownership, we have set up a corporate structure that will make it harder for outside parties to take over or influence Google. This [dual-class] structure will also make it easier for our management team to follow the long term, innovative approach emphasized earlier ....

The main effect of this structure is likely to leave our team, especially Sergey [Brin] and me, with increasingly significant control over the company's decisions and fate, as Google shares change hands ... New investors will fully share in Google's long term economic future but will have little ability to influence its strategic decisions through their voting rights.

... From the point of view of long term success in advancing a company's core values, the structure has clearly been an advantage.

Some academic studies have shown that from a purely economic point of view, dual class structures have not harmed the share price of companies .... 
Entrepreneurs who do not have sufficient personal capital to own a controlling block of the equity shares of their companies may seek control through dual-class stock structures. These structures allow them to leverage their pro rata equity positions with special shares carrying more votes than the shares held by other shareholders with equal equity ownership.

Entrepreneurs have sought dual-class share protection in greater numbers in recent years as activist investors and institutional investors have asserted themselves more actively in corporate governance matters. 104 Proponents of private ordering in corporate governance argue that the rise of activist and institutional investors has created an environment in which directors and managers feel pressured to make decisions raising stock prices in the near term, as opposed to pursuing long-term plans for value creation. 105 The precise magnitude of the increase in dual-class IPOs as a percentage of all IPOs is unclear, in part due to the definitional problems around dual-class share structures

Google has prospered as a private company. We believe a dual-class voting structure will enable Google, as a public company, to retain many of the positive aspects of being private.

Google, Inc., Amendment No. 9 to Registration Statement (Form S-1/A), 2930 (Aug. 18, 2004), https://www.sec.gov/Archives/edgar/data/1288776/ 000119312504142742/ds1a.htm [http://perma.cc/QR3A-EPDW]. In explaining the need for a recapitalization to introduce non-voting stock, Google's entrepreneur-controllers repeated this theme: "Technology products often require significant investment over many years to fulfill their potential. For example, it took over three years to ship our first Android handset, and then another three years on top of that before the operating system truly reached critical mass." Letter from Larry Page \& Sergey Brin (Apr. 2012), https://abc.xyz/investor/founders-letters/2011 [http://perma.cc/87CS-952J].

104 See David J. Berger, Partner, Wilson Sonsini Goodrich \& Rosati, Presentation at the Meeting of the SEC Investor Advisory Committee, Multi-Class Stock and the Modern Corporation: A View from the Left (Coast) on Governance Misalignment and the Public Company 5-6 (Mar. 9, 2017), https://www.sec.gov/spotlight/investor-advisory-committee2012/berger-remarks-iac-030917.pdf [http://perma.cc/UJ6S-4WGK]. 105 Id. 
described in the notes to Part II supra, but the trend towards more dual-class IPOs is clear. 106 Among companies in the dual-class data set, twenty-three went public in the period 2000-2009, while seventy-two went public in the period 20102017.

\section{B. Investors Seek Control to Minimize Value Destruction}

Investors resist dual-class stock structures based on principle, insisting that one share, one vote is the only appropriate corporate governance norm, and based on concerns about value destruction through selfaggrandizement or poor business decisions by founders. ${ }^{107}$ Investors value control because it allows them to minimize agency costs and value destruction by exerting influence over corporate strategy, and electing directors who will dismiss managers who are destroying value.

The traditional critique of dual-class stock structures is that they create significant incentives for entrenched management owners to seek pecuniary and non-pecuniary private benefits of control, misappropriating or destroying corporate value in the process. 108 These efforts to divert

106 One frequently cited statistic is that about fifteen percent of the technology companies that went public between 2012 and 2016 used dualclass share structures, versus only eight percent of such companies between 2007 and 2011. Maureen Farrell, Tech Founders Want IPO Riches Without Those Pesky Shareholders, WALL ST. J. (Apr. 3, 2017, 12:24 PM), https://www.wsj.com/articles/control-geeks-tech-founders-want-ipoinvestors-not-their-input-1491236464 (on file with the Columbia Business Law Review) (citing data compiled by University of Florida finance professor Jay Ritter).

107 See Richard Teitelbaum, Index Firms Take Issue with Nonvoting

Rights, WALL ST. J. (Apr. 9, 2017, 8:00 AM), https://www.wsj.com/articles/ index-firms-take-issue-with-nonvoting-rights-1491739227 (on file with the Columbia Business Law Review); Letter from Ken Bertsch, Council of Institutional Inv'rs (Apr. 27, 2017), http://www.cii.org/files/20170426\% 20CII\%20comment\%20S\&P\%20no\%20vote\%20share(1).pdf [https://perma.cc/Q35B-RYZD].

108 Traditionally, critics of dual-class share structures have argued that such ownership structures create significant risks of substantial 
corporate value to individual purposes are referred to as agency costs. Leaving founders in control of companies postIPO presents risks of two kinds of agency costs: management agency costs and control agency costs. Management agency costs arise from mismanagement-including reduced commitment, shirking, and pursuit of acquisitions to increase size or achieve diversification without generating value. 109 Control agency costs involve takings-directly diverting pecuniary private benefits to the controller through excessive pay, related-party transactions, and other methods of diverting corporate value to the controller. 110

Control agency costs can be controlled through fiduciary duties and liability rules, giving courts the power to intervene and impose penalties on entrepreneur-controllers who take advantage of their positions to benefit themselves. Management agency costs are harder to limit than control agency costs because, by their nature, they are mostly subject to business judgment review.111 Courts cannot place themselves in the position of second-guessing management decisions about corporate strategy. 112

Some scholars argue that the risk of management agency costs increases over time-that is, even if the founder's vision produces tremendous corporate value in the first few years after going public, either the business vision or the founder's

agency costs as controllers have incentives to seek private benefits of control. See, e.g., Lucian Arye Bebchuk, Reinier Kraakman \& George G. Triantis, Stock Pyramids, Cross-Ownership and Dual-Class Equity: The Mechanisms and Agency Costs of Separating Control from Cash-Flow Rights, in CONCENTRATED CORPORATE OWNERSHIP 295, 301-02 (Randall K. Morck ed., 2000) (explaining the agency costs inherent in companies with controlling-minority structure, one of which includes dual-class stock structures); Goshen \& Hamdani, supra note 12, at 565.

109 Goshen \& Hamdani, supra note 12, at 581-82.

$110 I d$.

111 Id. at 587-88.

112 See, e.g., In re Walt Disney Co. Derivative Litig., 907 A.2d 693, 698 (Del. Ch. 2005) (stating that "redress for [directors'] failures . . . must come from the markets, through the action of shareholders and the free flow of capital, and not from this Court"). 
acumen to execute it decline in later years. 113 If this occurs, the founder may be more apt to make poor business decisions that impose management agency costs on the shareholders. While there is no persuasive evidence that founder capabilities always atrophy with time, there are certainly firms that have withered under founder management after showing initial promise. 114 Two recent articles in the financial literature suggest the value of the dual-class structure declines over time, but they have significant shortcomings. 115

113 Lucian A. Bebchuk \& Kobi Kastiel, The Untenable Case for Perpetual Dual-Class Stock, 103 VA. L. REV. 585, 604-05 (2017); see also Jeffrey N. Gordon, Columbia Law Sch., Dual Class Common Stock: The Transformation of Markets Meets the Transformation of Control (Mar. 22, 2017) (on file with the Columbia Business Law Review) (noting that the original owner's influence over the vision of the company often wanes in the years after the IPO).

114 Yahoo! is one example that people sometimes raise to illustrate atrophy of entrepreneurial vision over time since founder Jerry Yang became CEO of Yahoo! as it was eclipsed by Google and before it became the target of an unsolicited bid from Microsoft. However, while they remained directors for many years, Yang and David Filo, the other founder, had ceded day-to-day management of the firm to a professional manager-Tim Koogle-before its initial public offering.

115 Cremers, Lauterbach, and Pajuste argue that dual-class firms enjoy valuation premiums over similarly situated single-class firms, as measured by Tobin's $Q$, at the time of their respective IPOs, but the premium dissipates over time and becomes a discount after six years from the IPO. Martijn Cremers, Beni Lauterbach \& Anete Pajuste, The Life-Cycle of Dual Class Firms 27-28 (European Corp. Governance Inst., Working Paper No. 550/2018, 2018), https://papers.ssrn.com/sol3/papers.cfm?abstract_id= 3062895 [http://perma.cc/BW6A-YTAJ]. Apart from the fact that the attribution is purely speculative, there are other significant problems with their conclusions. First, they rely on the multi-class IPO database created by Professor Jay Ritter of the University of Florida. Id. at 16 (citing Jay R. Ritter, IPO Data, U. FlA. WARRINGTON C. Bus., https://site.warrington.ufl.edu/ritter/ipo-data/__[https://perma.cc/7WRNBGJM]). Ritter's data includes many firms that are multi-class, but not dual-class, so there is no wedge between the economic and voting interests of insiders that have a class of shares different from the publicly listed class of shares. See id. (explaining the use of Ritter's data to construct their sample). Second, their conclusions regarding valuation premiums rely on measurements using Simple Q, rather than Total Q, and as they note in 
The risk of management agency costs can theoretically be mitigated through greater equity ownership of the company by the controller (i.e., forcing the controller to bear a greater share of the costs of poor decisions) or subjecting management to the market for corporate control. Concentrated ownershipthat is, control through ownership of a majority or other controlling position of common equity-can be expected to diminish management agency costs because the founder has a pro rata equity stake and internalizes all of the costs and benefits of management choices as much as other shareholders do. 116 This promotes more discipline regarding management decisions and less incentive to pursue private benefits of control. ${ }^{117}$

their paper, "the Total $\mathrm{Q}$ matched analysis favors dual class firms, and suggests the dual class structure may not be detrimental at all." Id. at 30 .

A second recent financial paper also relies on Simple Q to come to conclusions similar to those in Cremers, Lauterbach and Pajuste. See Hyunseob Kim \& Roni Michaely, Sticking Around Too Long? Dynamics of the Benefits of Dual-Class Structures 4-5 (Jul. 15, 2018) (unpublished manuscript), https://papers.ssrn.com/sol3/papers.cfm?abstract_id=3145209 [http://perma.cc/G4S3-6NXU]. As a valuation measure, Total Q is superior to Simple Q because it includes intangible assets in the denominator, which are omitted from the denominator of the latter. See, e.g., Ryan H. Peters \& Lucian A. Taylor, Intangible Capital and the Investment-Q Relation, $123 \mathrm{~J}$. FIN. ECON. 251, 252-53 (2017). Tobin's Q has, in any event, been seriously questioned as a means of measuring the effect of corporate governance changes on firm performance in both the financial and legal literature. See Robert Bartlett \& Frank Partnoy, The Misuse of Tobin's Q 50 (Feb. 4, 2018) (unpublished manuscript), https://papers.ssrn.com/sol3/papers.cfm? abstract_id=3118020 [http://perma.cc/978S-7TAF]; Philip H. Dybvig \& Mitch Warachka, Tobin's Q Does Not Measure Firm Performance: Theory, Empirics and Alternatives 25 (Mar. 6, 2015) (unpublished manuscript), https://papers.ssrn.com/sol3/papers.cfm?abstract_id=1562444

[http://perma.cc/9B3Z-NVYM].

116 Goshen \& Hamdani, supra note 12, at 591-93; see also Michael C. Jensen \& William H. Meckling, Theory of the Firm: Managerial Behavior, Agency Costs and Ownership Structure, 3 J. Fin. Econ. 305, 312-13 (1976) (stating that as an owner-manager's equity interest in a company is transferred to outside shareholders, agency costs increase).

117 Goshen \& Hamdani, supra note 12, at 591-93; see also Jensen \& Meckling, supra note 116, at 312-13. 
Dual-class stock structures, on the other hand, increase the risk of management agency costs, as controllers own less of the cash-flow rights in the company compared to other shareholders while retaining voting control. Dual-class controllers have "less skin in the game" and internalize a smaller portion of the costs of any mistakes they make in management decisions. With a smaller equity stake, or smaller claim to the cash flows of the company, the controller absorbs a smaller fraction of the negative effects of her decisions while continuing to capture the full private benefits of control.118

Competition can also limit both management and control agency costs as controllers are compelled to use corporate resources for competitive advantage in the market rather than personal gain or pet projects. 119 Competition can affect both dual-class controllers and concentrated ownership controllers.

\section{The Current Debate: Prohibition vs. Private Ordering}

At present, the competing claims of founders and investors for control of public companies in the United States have created a polarized debate regarding dual-class stock structures. Investor advocates argue that dual-class stock structures should be prohibited or strictly limited in time. ${ }^{120}$

118 Bebchuk \& Kastiel, supra note 113, at 602-04; Bebchuk et al., supra note 108 , at 301.

119 See Gilson, supra note 11, at 1658 (noting that when competition in the product market is sufficiently intense, the comparative advantage between monitoring by a controlling shareholder and by market-based monitoring converge); Mark J. Roe, Rents and their Corporate Consequences, 53 STAN. L. REV. 1463, 1468-69, 1473 (2001).

120 The Council of Institutional Investors, for instance, recently petitioned the New York Stock Exchange to require companies adopting dual-class structures to include time-based sunset provisions. Letter from Ash Williams, Chair, CII, Jeff Mahoney, Gen. Counsel, CII \& Ken Bertsch, Exec. Dir., CII, to Elizabeth King, Chief Regulatory Officer, Intercontinential Exchange, Inc. (Oct. 24, 2018) [hereinafter "CII Letter to NYSE”], https://www.cii.org/files/issues_and_advocacy/ 
Founder advocates argue that the current system of private ordering-through which founders choose their capital structure and invite investors to invest or not-is fair and efficient and should not be disturbed. ${ }^{121}$ Thus, participants in the U.S. capital markets are at loggerheads.

\section{Calls for Prohibition}

Institutional investors are pressing Nasdaq and the NYSE to change the rules of the game by prohibiting dual-class share structures altogether. ${ }^{122}$ They seek help from the exchanges and the SEC, which oversees the exchanges' activities, because they do not like the results occurring in recent private bargaining between the parties to initial public offerings. Institutional investors suffer from a collective action problem in opposing dual-class structures.

The problem is a version of the prisoner's dilemmaalthough, according to their anti-dual-class philosophy, all investors would be better off if no investors invested in dualclass IPOs (because companies would be forced to adopt a one share, one vote stock structure), no investor wants to be the one left out if other investors invest in a dual-class company that performs well in the market.123 Thus, it is difficult for

correspondence/2018/20181024\%20NYSE\%20Petition\%20on\%20Multiclass \%20Sunsets\%20FINAL.pdf [https://perma.cc/X6GX-5R7Y].

121 See, e.g., The Continuing Support for Dual-Class Stock by Companies and Investors, WILsON SONSINI GOODRICH \& Rosati (Oct.17, 2017), https://www.wsgr.com/WSGR/Display.aspx?SectionName= publications/PDFSearch/wsgralert-dual-class-stock-1017.htm [https://perma.cc/4ZZP-KYE9].

122 See CII Letter to NYSE, supra note 120. CII sent a similar letter to Nasdaq. Letter from Ash Williams, Chair, CII, Jeff Mahoney, Gen. Counsel, CII \& Ken Bertsch, Exec. Dir., CII, to John Zecca, Senior Vice President, Gen. Counsel N. Am. and Chief Regulatory Officer, Nasdaq Stock Market (Oct. 24, 2018), https://www.cii.org/files/issues_and_ advocacy/correspondence/2018/20181024\%20NASDAQ\%20Petition\%20on \%20Multiclass\%20Sunsets\%20FINAL.pdf [https://perma.cc/WMK3-RBL8].

123 Andrew Winden \& Andrew C. Baker, Dual-Class Index Exclusion 9-10 (Rock Ctr. for Corp. Governance, Working Paper Series No. 233, 2018), https://papers.ssrn.com/sol3/papers.cfm?abstract_id=3201578 [https://perma.cc/GRX6-YTK6]. 
institutional investors to pass up promising investments even if they do not like the associated corporate governance structures, particularly if their competitors are investing despite any such dissatisfaction. For example, T. Rowe Price quickly backed away from an initial challenge of the nonvoting dual-class structure adopted by Snapchat owners in connection with its 2017 initial public offering. 124

The Council of Institutional Investors has acknowledged that competition for investment assets (such as retirement accounts) among asset managers makes it difficult for them to forgo investments in companies with dual-class share structures.125 Corporate governance professionals employed at institutional investors know that their portfolio managers will refuse to sell (or not buy) the shares of successful companies simply because the company adopted a dual-class structure and refuses to collapse them into a single-class. ${ }^{126}$

In response to their collective action problem, institutional investors want to establish "one share, one vote" as an unshakeable bedrock principle of corporate governanceeven though state legislatures have not established such a principle in state corporate laws. ${ }^{127}$ In the absence of

124 Stephen Babcock, T. Rowe Price Backs off Challenge to Snapchat IPO Plans, Technical.Ly|BALT. (Jan. 20, 2017, 10:12 AM), https://technical.ly/baltimore/2017/01/20/t-rowe-price-snapchat-ipo/ [https://perma.cc/VHQ4-WHGY]; Paresh Dave, Big Investor T. Rowe Price Challenges Snapchat Founder's Power, L.A. Times (Jan. 19, 2017, 12:20 PM), http://www.latimes.com/business/technology/la-fi-tn-snapchat-voting20170119-story.html [https://perma.cc/38ML-654V].

125 See Ken Bertsch, Exec. Dir., Council of Institutional Inv'rs, Remarks to the SEC Investor Advisory Committee (Mar. 9, 2017), https://www.sec.gov/video/webcast-archiveplayer.shtml?document_id=030917iac [https://perma.cc/7WXH-YNVK].

126 See, e.g., Matt Levine, ISS Tells Investors How They Want to Vote, BLOOMBERG (Jan. 30, 2018, 10:05 AM), https:/www.bloomberg.com/ opinion/articles/2018-01-30/iss-tells-investors-how-they-want-to-vote [https://perma.cc/G2QK-2N3W]; see also John Crabb, Blue Apron's No-Vote Shares IPO Concerns Investors, INT'L FIN. L. REV. (June 28, 2017), http://www.iflr.com/Article/3728513/Blue-Aprons-no-vote-shares-IPOconcerns-investors.html [https://perma.cc/2SVA-BHBU].

127 See, e.g., Cal. State Teachers' Ret. Sys., Corporate Governance PRINCIPLES (2017), http://www.calstrs.com/sites/main/files/file- 
statutory or regulatory prohibition, they directly lobby companies to refrain from adopting dual-class structures or to include strict time-based sunset provisions if they utilize them. 128

To bolster their calls for prohibition or extinction of dualclass share structures, institutional investors sometimes argue that dual-class structures destroy corporate value. However, the empirical record on that issue is decidedly mixed. While a number of studies suggest that dual-class firms perform poorly compared to single class firms, 129 other studies suggest that a dual-class structure can enhance firm

attachments/corporate_governance_principles_1.pdf

[https://perma.cc/VXL7-BFZ3]; INT'L CORP. GOVERNANCE NETwORK, ICGN Viewpoint, Differential Share OWNership Structures: Mitigating Private Benefits of Control AT the Expense of Minority SHareholders (2017), https://www.icgn.org/sites/default/files/ICGN\%20Viewpoint\%20 differential\%20share\%20ownership_0.pdf [https://perma.cc/AE4X-NZ54]; Letter from Ann Yerger, Exec. Dir., Council of Institutional Inv'rs, to Judith C. McLevey, Vice President, Corp. Actions \& Mkt. Watch, NYSE Euronext (Dec. 10, 2012) [hereinafter Yerger Letter] (on file with the Columbia Business Law Review).

128 See, e.g., Corporate Governance Principles for US Listed Companies, supra note 9 .

129 Renée Adams \& Daniel Ferreira, One Share-One Vote: The Empirical Evidence, 12 REV. FIN. 51, 85 (2008) (finding some support in the literature for the hypothesis that deviations from one share, one vote adversely affect the value of non-control equity); Paul A. Gompers, Joy Ishii \& Andrew Metrick, Extreme Governance: An Analysis of Dual-Class Firms in the United States, 23 REV. Fin. STUD. 1051, 1084-85 (2010) (finding that firm value increases with insiders' cash-flow rights and decreases with insiders' voting rights); Ronald W. Masulis, Cong Wang \& Fei Xie, Agency Problems at Dual-Class Companies, 64 J. FIN. 1697, 1721-22 (2009); Scott B. Smart, Ramabhadran S. Thirumalai \& Chad J. Zutter, What's in a Vote? The Short-and Long-Run Impact of Dual-Class Equity on IPO Firm Values, 45 J. ACCT. \& ECON. 94, 96 (2008); see also InV'R RESPONSIBILITY RESEARCH Ctr. Inst., Controlled Companies in the Standard AND Poor's 1500: A TEN Year PERFormance AND RISK REview (2012) (finding that noncontrolled firms outperformed controlled firms over a ten-year period ended August 31, 2012); KAMONJOH, supra note 15, at 10 (finding controlled companies underperformed non-controlled firms over all periods reviewed (one-, three-, five- and ten-year periods) with respect to total shareholder returns, revenue growth, return on equity, and dividend payout ratios). 
value.130 One study concluded that founder-CEOs tend to retire from management when the firms they establish perform particularly well, and founder-CEOs have a positive effect on firm performance. 131 So it is hard to conclude that founder control is clearly adverse to corporate value creation.

130 Ekkehart Böhmer, Gary C. Sanger \& Sanjay B. Varshney, The Effect of Consolidated Control on Firm Performance: The Case of Dual-Class IPOs, in EMPIRICAL ISSUES IN RAISING EQUITY CAPITAL 95, 115 (Mario Levis ed., 1996) (finding for a sample of ninety-eight dual-class IPOs that dualclass firms outperform their single-class counterparts matched for exchange, offer date, industry and size in terms of stock-market returns as well as accounting measures of firm performance); Thomas J. Chemmanur \& Yawen Jiao, Dual-Class IPOs: A Theoretical Analysis, 36 J. BAnkInG \& FIN. 305, 306 (2012) (creating a model predicting that dual-class IPO firms are likely to outperform (underperform) single class IPO firms if the reputation of the incumbent is high (low) and the firm is operating in an industry where the difference in intrinsic values between the projects with high and low near-term uncertainty is large (small));Valentin Dimitrov \& Prem C. Jain, Recapitalization of One Class of Common Stock into DualClass: Growth and Long-Run Stock Returns, 12 J. CoRP. FIN. 342 (2006) (finding a group of 178 firms that recapitalized from one-share one-vote into a dual-class structure between 1979 and 1998 experienced, on average, significant positive abnormal returns of $23.11 \%$ in a period of four years following the announcement of the recap, with higher abnormal returns accruing when additional equity is issued to grow the firm).

131 Renée Adams, Heitor Almeida \& Daniel Ferreira, Understanding the Relationship Between Founder-CEOs and Firm Performance, $16 \mathrm{~J}$. EMPIRICAL FIN. 136, 136 (2009) (finding that good performance makes it less likely that the founder retains the CEO title and that, after factoring out the effect of performance on founder-CEO status, there is a positive causal effect of founder-CEOs on firm performance that is quantitatively larger than the effect estimated through standard OLS regressions). Reid Hoffman of LinkedIn comes to mind. In fact, he is on record saying that he brought in an outside CEO because he knew he was not interested in the challenges of managing process in a large firm. However, he retained voting control of the company. Reid Hoffman, If, Why, and How Founders Should Hire a "Professional" CEO, REIDHOFFMAN.ORG (Jan. 21, 2013), https://www.reidhoffman.org/if-why-and-how-founders-should-hire-aprofessional-ceo-2/ [https://perma.cc/LQ9B-C4HH]; Cromwell Schubarth, Reid Hoffman: Why CEO Founders Should Stay and Why I Didn't at LinkedIn, Silicon VAlley Bus. J. (Jan. 22, 2013, 1:44 P.M.), https://www.bizjournals.com/sanjose/news/2013/01/22/reid-hoffman-whyceo-founders-should.html [https://perma.cc/4RMK-KL6S]. 


\section{Support for Private Ordering Status Quo}

In the absence of specific stock exchange or other regulatory requirements for dual-class capital structures, such structures are currently adopted through private ordering. That is, there is an implicit bargain regarding the governance of the company being struck between the entrepreneur and public investors at the time of an initial public offering. The entrepreneur offers investors a right to a pro rata share of the cash flows generated by the entrepreneur's enterprise in exchange for an investment of capital and investors' acceptance of the entrepreneur's control of the enterprise, subject to whatever limitations on that control are incorporated into the charter of the company and the underlying corporate law. Investors in a dual-class company make a bet on the founder and the founder's vision for creating corporate value-hopefully generating abovemarket returns on investment.

In the private ordering model, which depends on contractual freedom and market efficiency, investors and entrepreneurs can adopt different combinations of cash flow and control rights to balance entrepreneurs' interests in pursuing their idiosyncratic vision and investors' desire for protection from agency costs. 132 The outcome of negotiations regarding these combinations of rights depends on each party's relative bargaining power, and bargaining power depends in part on market dynamics. When a large amount of private capital is available and there is an insufficient supply of good new business ideas, or when an entrepreneur has a particularly compelling business idea or demonstrated ability to build a business, the entrepreneur can get better terms, including, in some cases, a dual-class stock structure. ${ }^{133}$ With a less compelling business idea, particularly if private capital for investment in start-ups is scarce, the entrepreneur will get

132 Goshen \& Hamdani, supra note 12, at 585-86.

133 Id. (citing Paul Gompers \& Josh Lerner, The Use of Covenants: An Empirical Analysis of Venture Partnership Agreements, 39 J.L. \& ECON. 463, 493 (1996) (finding that venture capital's use of covenants is related to supply and demand in the venture-capital industry)). 
less favorable terms and may have to give up the dual-class structure in order to go public or obtain sufficient capital to grow the business.

Thus, it should not be a surprise that in the current market, in which there is more capital than ideas and talent, ${ }^{134}$ a significant number of entrepreneurs are able to convince investors that they ought to be permitted to retain control of their company following an initial public offering, and investors are willing to invest in promising companies despite their distaste for corporate governance features that entrench the entrepreneur in control of the company. Indeed, some of today's dual-class companies (e.g., Alphabet, Facebook) are among the most successful companies in the world. 135

Proponents of private ordering support their position by noting that no one is forced to accept the founder's terms for investment-investors can always choose not to invest, and the risks of agency costs created by the dual-class governance model are priced into the IPO share price by the market, which has the ability to assess and price such risks. 136 If we

134 See Will Gaybrick, Tech's Ultimate Success: Software Developers Are Now More Valuable to Companies than Money, CNBC (Sept. 6, 2018, 3:19 PM), https://www.cnbc.com/2018/09/06/companies-worry-more-aboutaccess-to-software-developers-than-capital.html [https://perma.cc/JP68$\mathrm{UZNR}]$.

135 See David J. Berger, Dual-Class Stock and Private Ordering: A System that Works, HARV. L. SCH. F. ON CoRP. GovernANCE \& Fin. REG. (May 24, 2017), https://corpgov.law.harvard.edu/2017/05-24/dual-class-stockand-private-ordering-a-system-that-works/ [https://perma.cc/P23L-HDR7] (arguing that the current private ordering system works and dual-class arrangements are in part a response to short-termism in the financial markets).

136 Stephen Bainbridge, Bebchuk and Kastiel's Paternalistic Take on Perpetual Dual-Class Stock, ProfessorBainBridge.com (May 11, 2017), http://www.professorbainbridge.com/professorbainbridgecom/2017/05/bebc huk-and-kastiels-paternalistic-take-on-perpetual-dual-class-stock.html [https://perma.cc/3GB7-NN9W]. But see, Bebchuk \& Kastiel, supra note 113, at 622 (arguing that while "IPO buyers might pay attention to and price a salient feature like a dual-class structure, they might not similarly price more subtle features, such as the presence and specifics of a sunset provision."). 
assume that markets are efficient, the governance structure should be priced into the value and offering price of a company at the time of its IPO. Thus, advocates of private ordering argue that if the entrepreneur is willing to accept a lower value for the company at the time of the IPO, and investors are willing to purchase shares at the market price for a chance to benefit from the entrepreneur's vision, a fair bargain is struck. Accordingly, investors should not seek voting rights they have not paid for (with respect to existing dual-class companies) or advocate for prohibition of a corporate governance model that has been accepted by the market and produced significant value for the world economy.

In the private ordering model, markets adjust for poor management decisions by terminating managers or divesting. In the case of dual-class companies, termination is not an option for investors, since the entrepreneur controls the vote. Thus, the only available response to mismanagement is exit, which may or may not be an available option, depending on the investor's business model.137 Even where available, selling shares may, in any event, only arise too late to avoid the value destruction caused by entrepreneur-controllers who are not effectively accountable to the market. Critics of the current private ordering status quo conclude that rules limiting the use of dual-class governance structures are

137 Institutional investors typically say that they are not able to "just sell," or do the "Wall Street Walk," if they are dissatisfied with the management of an entrepreneur-controller because they often invest in a manner intended to follow the market or important indices such as the S\&P 500, meaning they must own every company in the relevant index, regardless of corporate governance structure and management decisions. See, e.g., Yerger Letter, supra note 127 (stating that "[d]ue to their heavy use of passive strategies, CII members are unable to exercise the 'Wall Street Walk' and simply sell if they are dissatisfied"); see also Rakhi Kumar, Managing Dir., Head of ESG Investments and Asset Stewardship, State St. Glob. Advisors, Remarks to the SEC Investor Advisory Committee (Mar. 9, 2017), https://www.sec.gov/video/webcast-archiveplayer.shtml?document_id=030917iac [https://perma.cc/7WXH-YNVK]. 
necessary to protect investors against such value destruction. 138

The next Section suggests that dual-class stock structures can obtain enhanced legitimacy by focusing on the fundamental goals of the parties to a corporate charter agreement (their mutually ideal complete contract). The goal of the founder is unimpeded pursuit of a vision of value creation and the goals of investors are voice and influence on management decisions. As explained in Part VII, there are numerous ways in which dual-class stock structures can be designed to satisfy both goals, making prohibition or strict time limitation unnecessary.

\section{Alternative Standards for Assessing Dual-Class Stock Structures}

In evaluating the terms of dual-class stock structures, it is important to start at the beginning - the fundamental deal struck between the buyers and sellers of such structures. As noted above, the deal is a capital investment by investors in exchange for a claim on some of the value created by the entrepreneur's vision. Where the entrepreneur is not investing in the enterprise with other investors on a one-toone pro rata basis, investors are essentially making their investment decision based only on their belief in the founder's vision and their desire to own a piece of it. 139 Because the entrepreneur's economic skin in the game is comparatively low, the importance of the entrepreneur's idiosyncratic vision is particularly high.

In light of this bargain between founders and investors, the terms of the dual-class stock structure should be designed and evaluated based on the extent to which they are necessary to

138 See, e.g., Blair A. Nicholas \& Brandon Marsh, The Rising Tide of Dual-Class Shares: Recipe for Executive Entrenchment, Underperformance, and Erosion of Shareholder Rights, NAPPA REP., Apr. 2017, at 4 ("If the only solution is for investors to abandon certain investments after dual-class systems have done their damage, owners lose out financially and discussions in corporate boardrooms and C-suites across the country will suffer from a lack of diversity, perspective, and accountability.").

139 See Goshen \& Hamdani, supra note 12, at 595 n.107. 
support the idiosyncratic vision for value creation held by the founder, while minimizing the costs to investors. The structure should give the founder unfettered discretion to pursue the vision, but not more than necessary. The structure should also protect investors by giving them some influence over management, but not the ability to control over the strategic direction of the company or election of its managers.

Particularly in the current market environment of abundant capital chasing a limited number of visions for value creation, a system that provides entrepreneurs too little protection may discourage or prevent them from pursuing visions that could create significant value, leading to a loss for society. Conversely, a system that gives entrepreneurs too much protection may lead to unacceptable levels of management agency costs through value destroying, goodfaith management mistakes regarding asset allocation, even if no conflicted or otherwise self-aggrandizing aggregations of pecuniary private benefits of control are present.140

On the other hand, if institutional investors are successful in their campaign to abolish dual-class structures or to impose strict time-based sunsets on them, the result may very well be an acceleration of business trends that are already emerging in the United States. More companies would stay private longer, leading to diminished opportunities for investment by retail investors and less publicly available information about the most vibrant engines of growth in the economy. Why go public and lose control of your company when you can get the capital you need to grow in the private markets, retain control

140 It is also possible that in some cases entrepreneur-controllers make poor corporate management decisions based on the pursuit of non-pecuniary private benefits of control. Entrepreneur-controllers may, for instance, make business decisions based on pride, fame or personal satisfaction, see Alessio M. Pacces, Control Matters: Law and Economics of Private Benefits of Control 5-6 (European Corp. Governance Inst., Working Paper No. 131/2009, 2009), https://papers.ssrn.com/sol3/papers.cfm?abstract_id= 1448164 [https://perma.cc/R47D-XZJW] (explaining how idiosyncratic nonpecuniary private benefits of control affect business decisions), or enter into businesses they do not know well but find personally alluring. See Kobi Kastiel, Against All Odds: Hedge Fund Activism in Controlled Companies, 2016 Colum. Bus. L. REv. 60, 118-19 (2016). 
and avoid the harsh spotlight of public disclosure of your business activities and results of operations? Private ordering may permit some inefficient results, but prohibition or significant limitation of dual-class structures could have adverse macro-economic effects by discouraging entrepreneurs from going public and growing their enterprises using the additional capital available in public markets.

Entrepreneurs often face a trade-off between acquiring additional capital to grow their firms and retaining control over the enterprise they have created.141 If entrepreneurs are able to convince private or public investment markets that they have sufficiently compelling idiosyncratic visions for value creation and that they deserve protection from termination through the creation of dual-class share structures, they can pursue the growth of their firms without fear of losing control over them. If entrepreneurs are prohibited from relying on dual-class structures to enhance their voting strength even as their economic interest in their firm declines, they may choose not to seek value-enhancing capital infusions lest they lose control of their vision. Noam Wasserman has shown that entrepreneurs sometimes choose not to grow their companies if they fear seeking the capital necessary to grow will cause them to lose control.142 For example, in his recent autobiography, Phil Knight suggested that he would not have been willing to take Nike public without the right to retain control of the board.143 Nasdaq

141 See Noam Wasserman, The Throne Vs. the Kingdom: Founder Control and Value Creation in Startups, 38 STRATEGIC MGMT. J. 255, 256 (2017) (arguing 'founders face a 'control dilemma' in which a startup's resource dependence drives a wedge between the startup's value and the founder's ability to retain control of decision making" and finding that in a unique data set of 6130 U.S. startups, those in which the founder is still in control of the board of directors and/or the CEO position are significantly less valuable than those in which the founder has given up control, with each additional level of founder control (i.e., controlling the board and/or the CEO position) reducing the pre-money valuation of the startup by $17.1 \%$ $22.0 \%$, on average).

142 See Wasserman, supra note 103, at 108.

143 Phil Knight, Shoe Dog 329-30 (2016). 
recently issued a report on market reforms -in an effort to reverse the U.S. trend of fewer and fewer public companiesin which it voiced support for dual-class stock structures that offer founders flexibility in making the decision to go public. ${ }^{144}$

Goshen and Hamdani argue that entrepreneurs should be permitted to contract with investors for uncontestable control in order to pursue their idiosyncratic visions. 145 Thereafter, the entrepreneur-controller's right to make management decisions should be afforded property-rule protection-that is, it should only be taken away with the owner's consent.146 The uncontestable and (most often) indefinite control an entrepreneur has in a dual-class context provides the entrepreneur with the maximum ability to realize her idiosyncratic vision, which can benefit both the entrepreneur and her investors. However, the entrepreneur's smaller equity claim as compared to concentrated ownership leaves investors with relatively high exposure to agency costs. 147

Because of this relatively high risk, investors have a particularly acute need for a voice-a means to hold management accountable-in the context of dual-class companies. The heart of the challenge in resolving the contest for control between entrepreneurs and institutional investors is finding a way to protect investors from management agency costs - essentially, the prospect of poor management decisions made by a manger with uncontested discretion. A welldesigned package of dual-class sunrise and sunset provisions

144 Nasdaq, The Promise of Market Reform: Reigniting America's ECONOMIC ENGINE 17 (2018) ("One of America's greatest strengths is that we are a magnet for entrepreneurship and innovation. Central to cultivating this strength is establishing multiple paths entrepreneurs can take to public markets. Each publicly-traded company should have flexibility to determine a class structure that is most appropriate and beneficial for them, so long as this structure is transparent and disclosed up-front so that investors have complete visibility into the company. Dualclass structures allow investors to invest side-by-side with innovators and high growth companies, enjoying the financial benefits of these companies' success.").

145 Goshen \& Hamdani, supra note 12, at 598-99.

146 Id. at 601.

147 Id. at 590-91. 
will give entrepreneurs the security and discretion they seek while protecting investors from the risk of material value destruction through poor decisions by offering investors a means to influence the entrepreneur's decisions, if not to interfere with them.

Thus, in evaluating the terms of dual-class stock structures, the parties should ask the following questions: Does the term support pursuit of the entrepreneur's idiosyncratic vision? Does the term contemplate a means for investors to influence management? Is the term necessary to avoid agency costs? Is there a less restrictive means to avoid agency costs? Through an examination of these questions, it is possible to provide investors with more protection from agency costs than they typically have in current dual-class stock structures but without prohibiting or severely limiting the use of such capital structures to promote the pursuit of entrepreneurial visions for value creation. In fact, as discussed in Part VII, there are multiple different approaches that could be used to protect investors more effectively without prohibition or time-limitation of the structures.

\section{DESIGNING OPTIMAL DUAL-CLASS STRUCTURES}

\section{A. Summary}

The genius of American corporate law is its flexibility. The survey of dual-class sunrise and sunset structures in Parts II and III above show that there are many ways to approach a dual-class share structure and it should be possible to design multiple different structures that meet the needs of both entrepreneurs and investors. Prohibition and strict timebased limitation are neither necessary nor appropriate given the plethora of other alternatives, even if one is not comfortable with the status quo result arising from unrestricted private ordering.

The optimal dual-class capital structure will be driven by the characteristics of a given situation and should be negotiated among the parties prior to an initial public offering considering the nature of the company and its vision, the 
strength of the vision, the personal qualities of the entrepreneur, the industry of the company, the capital profile and spending requirements of the company, the availability of alternatives to going public, and any other factors deemed material by the parties. 148 One size does not fit all, and allowing the market to decide the terms of control for each company should, in aggregate, result in the best allocation of resources to means of productivity and division of control between entrepreneurs and investors. 149

The optimal structure will typically arise from an appropriate mix of sunrise and sunset provisions. If the founder insists on issuing only no vote shares to public investors, a time-based sunset may be appropriate, so the

148 As noted supra Part V, a company typically has a capital structure in place before filing a registration statement with the SEC, launching the deal, and embarking upon the "road show" marketing tour in which it pitches the deal to investors. However, the initial public offering underwriting process provides an excellent forum in which founders, their counsel, their bankers, and investors can assess the merits of a dual-class structure. Investment bankers often organize "testing the waters" meetings between founder/CEOs and potential investors prior to filing a registration statement, which provide an opportunity to determine which entrepreneurs have idiosyncratic visions that merit dual-class protection and which do not, as well as the details of the dual-class structure for each company. See, e.g., Ned Welsh, Testing the Waters, MOFOJUMPSTARTER.COM (Mar. 11, 2014), https://www.mofojumpstarter.com/2014/03/11/testing-the-waters/ [https://perma.cc/G3JS-JN8J].

149 Ronald Gilson, Evaluating Dual-Class Common Stock: The Relevance of Substitutes, 73 VA. L. REV. 807, 828 n.56 (1987) (the market mechanism allows beneficial recapitalizations and financings to continue while deterring transactions that tend to disenfranchise and transfer wealth from public shareholders to insiders without appropriate compensation); Martin Lipton, New Theory in Corporate Governance Undermines Theories Relied on by Proponents of Short-Termism and Shareholder Activism, HARV. L. SCH. F. ON CORP. GOvERnANCE \& Fin. REG. (Nov. 25, 2016), https://corpgov.law.harvard.edu/2016/11/25/new-theory-incorporate-governance-undermines-theories-relied-on-by-proponents-ofshort-termism-and-shareholder-activism/ [https://perma.cc/JAD5-J2H4] (referring to Goshen and Squire's Principal Costs, and noting that the division of control between managers and investors that minimizes the sum of principal costs and agent costs is firm-specific, driven by factors such as industry, business strategy and personal characteristics of the manager and investors). 
period in which investors have no voice is limited. If public investors have the right to elect a minority of the directors on the board, the nature of the sunset provisions will be less important since investors have a significant avenue for input on and review of management decisions, including strategies that could lead to a diminution in corporate value, leading to management agency costs.

If a dual-class company adopts a minority director election provision, the nature of the voting and sunset provisions will be less important, but still offer opportunities for tailoring in light of the lessons of idiosyncratic vision theory. Generally, voting shares will be preferable to non-voting shares due to the lack of accountability and shareholder voice associated with non-voting shares. The precise ratio of high to low voting shares is less important, but a higher ratio is a preferable means to manage the founder's concerns about dilution over time, since it preserves a voice for shareholders in the company.

With respect to sunset provisions, time-based sunsets and dilution sunsets are generally inconsistent with supporting the realization of an idiosyncratic vision for value creation and should generally be avoided. Divestment, death, and separation sunsets are consistent with supporting an entrepreneurial vision for value creation, and should generally be included in the structure for dual-class companies. Other sunsets that put pressure on founders to focus on the efficient realization of their value enhancing vision without arbitrary or dis-incentivizing limitations include fiduciary and performance sunsets, which penalize founders for fiduciary breaches and failure to meet performance expectations. 150

The terms of a dual-class structure should accurately reflect the quality of a founder's idiosyncratic vision for creating above market returns, including the nature of the business, the position of the company in the market, and the talent of the company's management. There is significant

150 This author is not aware of any companies that have instituted such sunset provisions to date. 
room for flexibility within the dual-class structure to give some founders a greater benefit of the doubt (or a longer leash) than others in designing the structure. In a situation where a founder insists on a dual-class structure despite a dubious business model or lackluster talent, it may in fact be appropriate to include a time-based sunset provision, although as a theoretical matter it is still preferable to utilize a less arbitrary sunset tied to performance expectations or failures.

\section{B. Sunrise Provisions}

\section{Voting Structure}

Issuing only non-voting shares to public investors is a suboptimal approach to retaining founder control of a public company. While issuing non-voting stock to the public allows founders to improve the value of their company by using equity to raise capital, incentivize employees, and acquire accretive businesses without fear of losing control, there are numerous drawbacks to listing only non-voting shares. The shareholders' voice becomes extremely attenuated when management has no obligation to submit any matters to a vote of the public shareholders. SEC Rule 14a-8 under the Securities Exchange Act of 1934, which monitors the shareholder proposal process, is premised on shareholders holding voter shares. ${ }^{151}$ The SEC's say-on-pay voting requirement arguably applies under Rule 14a-21 only when a company is soliciting votes from shareholders for election of directors at an annual meeting pursuant to a Schedule 14A proxy statement. 152 If no public shareholder vote is required because the issuer has only non-voting shares listed, the issuer would use Schedule 14C, the proxy form used for annual meetings at which no vote of the public shareholders will take place, and Rule $14 \mathrm{a}-21$ would not apply. ${ }^{153}$ As a result, investors will effectively have no measurable voice, and

15117 C.F.R. $\S 240.14 \mathrm{a}-8$ (2018).

152 Id. $\S 240.14 \mathrm{a}-101 ; i d . \S 240.14 \mathrm{a}-21$.

153 Id. $\S 240.14 \mathrm{c}-101$. 
management will have little incentive to listen to their concerns about the direction of the company's strategy. The absence of investor voice is ultimately an issue of accountability. 154

Listing both voting and non-voting shares is less worrisome than listing only non-voting shares, because as long as there is a voting class of common equity listed, the accountability issues described above will be ameliorated. Some dual-class companies have taken this approach. 155 Another alternative to listing non-voting shares in an initial public offering is listing low voting shares but authorizing the issuance of future non-voting shares, if necessary, in the IPO charter. 156 In that case, public shareholders have arguably

154 Anne Simpson of CalPERS, a member of the SEC's Investor Advisory Committee, stated at the Committee's March 9, 2017 hearing on Unequal Voting Rights of Common Stock that shareholders ceding power without accountability is the primary problem with non-voting shares specifically and dual-class share structures more generally. Anne Simpson, Remarks to the SEC Investor Advisory Committee (Mar. 9, 2017), https://www.sec.gov/video/webcast-archiveplayer.shtml?document_id=030917iac [https://perma.cc/7WXH-YNVK].

155 See, e.g., Alphabet, Inc., Annual Report (Form 10-K) (Feb. 3, 2017), https://www.sec.gov/Archives/edgar/data/1652044/000165204417000008/go og10-kq42016.htm [https://perma.cc/X4WK-SEZB]; Brown-Forman Co., Annual Report (Form 10-K) (June 16, 2016), https://www.sec.gov/ Archives/edgar/data/14693/000001469316000160/bfb-2016430x10k.htm [https://perma.cc/9FQK-HJE6]; CBS Co., Annual Report (Form 10-K) (Feb. 16, 2016), https://www.sec.gov/Archives/edgar/data/813828/000081382816 000065/cbs_10k-123115.htm [https://perma.cc/PZ27-5UK9]; Discovery Comm'n, Inc., Annual Report (Form 10-K) (Feb. 28, 2018), https://www.sec.gov/Archives/edgar/data/1437107/000143710718000028/di sca-2017123110k.htm [https://perma.cc/LSS2-7H7Y]; Under Armour, Inc., Annual Report (Form 10-K) (Feb. 23, 2017), https://www.sec.gov/ Archives/edgar/data/1336917/000133691717000017/ua-20161231x10k.htm [https://perma.cc/BPN2-9EP9]; Viacom, Inc., Annual Report (Form 10-K) (Nov. 12, 2015), https://www.sec.gov/Archives/edgar/data/1339947/ 000133994715000042/via2015093010k.htm [https://perma.cc/5JD7-YPYR]. See also Andrew William Winden, Dual-Class Data Set (on file with the Columbia Business Law Review).

156 This is the approach taken by Blue Apron, Inc. in its recent IPO. See Blue Apron, Inc., Amendment No. 1 to Registration Statement (Form S-1/A) (June 19, 2017), https://www.sec.gov/Archives/edgar/data/1701114/ 000104746917004085/a2232430zs-1a.htm [https:/perma.cc/R8AD-TPBN]. 
agreed to such future issuances in agreeing to invest at the time of the initial public offering. Assuming adequate disclosure and risk factors regarding the possibility of offering non-voting shares in the future, it would not be necessary to make any payments to the public shareholders in connection with future issuances of the non-voting shares. As a practical matter, no later approval of a charter amendment by shareholders - the issue that became a challenge for Facebook-would be necessary. Furthermore, as a policy matter, any issuance would not constitute the kind of midcourse correction requiring restitution discussed by Goshen and Hamdani. 157

Another alternative to listing non-voting shares is a change in the ratio of votes between the high and low voting shares to ensure that future issuances of low voting shares for compensation, capital raising, and acquisition purposes do not dilute founders out of their control position in the company. There are no rules that require the ratio to be 10:1. As noted in Part III, supra, although 10:1 is the overwhelmingly most common ratio, there are some companies with other ratios. A founder concerned about losing control through future equity issuances can establish an initial ratio that is more impervious to dilution, such as 50:1 or 100:1.

\section{Minority Directors}

A large number of companies that adopted dual-class structures from the mid-70s to the mid-80s, when the NYSE refused to list companies with a dual-class structure, did so through the AMEX, which had rules requiring that minority shareholders have the power to elect a minority of the board of directors. 158

This option may be the best compromise between entrepreneurs' desire for management discretion and investors' desire for protection from poor management decisions. If investors are not able to rely on market discipline

157 See Goshen \& Hamdani, supra note 12, at 608-10.

158 Seligman, supra note 23 , at 703 . Nike is a striking example of a company that continues to operate on this basis. 
or bundling of control and cash flow rights to ameliorate the risks of management agency costs, giving investors one or more representatives on the board of directors is an important concession that can give investors a voice and mitigate the risk of such agency costs.

The introduction of minority director elections may work better for entrepreneur-controllers than time-based sunset provisions that might trigger before the entrepreneurcontroller's idiosyncratic vision for value creation is completely achieved. On the other hand, with the introduction of minority director elections, investors have an advocate in the boardroom. This may make it more difficult for entrepreneur-controllers to engage in long-term large-scale investments of corporate assets in losing propositions, particularly those that are based more on personal allure (non-pecuniary private benefits of control) than realistic visions for enhancing corporate value.

To be effective, this right should be coupled with proxy access and a clear right to nominate the minority directors. There is a significant likelihood that candidates nominated by a board elected by the founder will not be sufficiently independent to give minority investors a true voice in board deliberations. Accordingly, it is important that the minority investors' right to elect a certain percentage of the board be coupled with a right to nominate an equivalent number of directors and have those nominees included in the corporate proxy for consideration by shareholders along with other director nominees.

Management agency costs can be mitigated through an effective mechanism to allow public investors to nominate and elect a minority of the directors to the board. One or more truly independent representatives of the public investors can voice concerns about the amount or nature of capital investments or research and development expenses being devoted to particular projects of the company. Additionally, they can also voice concerns about the wisdom of an acquisition or the proposed price. At the end of the day, the founder will control the board and be able to obtain support for decisions that are consistent with the founder's 
idiosyncratic vision for value creation. However, the founder will also benefit from truly independent alternative perspectives provided by genuine representatives of the public investors.

Of course, introducing investor representatives to the board of directors is not without risks. Dual-class companies permitting public investors to elect a minority of the board are necessarily more vulnerable to activist investors, who can seek to place representatives in those seats, and, in fact, are targeted by activist investors twice as much as dual-class companies without such minority director representation. 159 Activist investors have used this access to force some dualclass companies to collapse their capital structures into a single class. 160

\section{Sunset Provisions}

\section{Time-Based Sunsets}

In light of concerns about the risk of founder vision atrophy and increased agency costs over time, Bebchuk and Kastiel have argued, in their article The Untenable Case for Perpetual Dual-class Stock, that if dual-class stock structures are not abolished, they should at least be required to include a time-

159 See Kastiel, supra note 140, at 95 (noting a sample of 193 dual-class firms shows that forty-three percent of all dual-class firms that grant public investors rights to elect a minority of directors experienced at least one activist event over a ten-year period from 2005 to 2014 as compared to twenty percent of all dual-class firms without such a structure).

160 Hubbell Incorporated reclassified into a single class of common stock in December, 2015. See Hubbell Inc., Current Report (Form 8-K) (Dec. 23, 2015), https://www.sec.gov/Archives/edgar/data/48898/000 119312515412174/d110573d8k.htm [https://perma.cc/494J-FNA6]; Ed Hammond \& Stephen Foley, Falcone Targets Dual-Class Share Hurdle, Fin. Times (June 25, 2014), https://www.ft.com/content/6b5f1726-fb99-11e3aa19-00144feab7de (on file with The Columbia Business Law Review); Update: Hubbell-Change in Trustee to Hubbell Family Trusts Has Moved Class A Shares from Steep Discount to Premium, SeEkIng AlPha (July 28, 2014, 3:59 PM), https://seekingalpha.com/article/2349235-update-hubbellchange-in-trustee-to-hubbell-family-trusts-has-moved-class-a-shares-fromsteep-discount-to-premium [https://perma.cc/5HT2-YJT3]. 
based sunset provision that is renewable at the discretion of the common stockholders. 161 Their concerns may be bolstered by recent financial studies suggesting the value of dual-class stock structures declines over time. 162

Despite this, time-based sunsets generally are not part of an optimal set of sunset provisions. The time-based sunsets currently in use are effectively arbitrary-they do not appear to be related in any way to the achievement or failure of any aspect of an entrepreneur-controller's idiosyncratic vision, short- or long-term performance, or value metrics. 163 While it might be possible to estimate how long it ought to take to realize the value of the entrepreneur's idiosyncratic vision, any such estimate, which may or may not be correct, is just that-an estimate. Sunset provisions reliant on estimates of how much discretion an entrepreneur needs are inconsistent with Goshen and Hamdani's idea that the entrepreneur should have a property right in control for purposes of pursuing an idiosyncratic vision and should not be forced to give up control without consent. ${ }^{164}$ Time-based sunsets are hostile to entrepreneurial discretion and reflect a strict view that the entrepreneur-controller's control of the company should simply end at some pre-determined time in the future. When insisting on a time-based sunset provision, shareholders are essentially telling the entrepreneurcontroller, "You only get X years. That's it." That is a blunt instrument, not calibrated to resolve the tension between the entrepreneur's desire for protection from interference or termination and the investors' desire for protection from poor management decisions that may or may not occur.

161 See Bebchuk \& Kastiel, supra note 113, at 617-21.

162 See supra note 115.

163 In terms of stock price performance among companies that have incorporated a time-based sunset provision in their charter, five experienced precipitous stock price declines post-IPO, seven experienced significant stock price gains following their IPO, and four meandered around their IPO price. Andrew William Winden, Dual-Class Data Set (on file with the Columbia Business Law Review).

164 See supra note 146 and accompanying text. 
One argument Bebchuk and Kastiel make in favor of timebased sunsets is that they are similar to the lifespans of private equity funds 165 - another situation in which investors give the managers of their investment's significant discretion regarding asset allocation with little or no ability to influence the choice of manager over time. As noted above, a plurality of the time-based sunsets observed in this data set were set at the seventh anniversary of the listing of the company, while a few were set at ten years. This period is similar to the lifespans of private equity funds, which tend to be around ten years. 166 Bebchuk and Kastiel suggest that the limited life of private equity funds represents an implicit understanding that the advantages of superior business leadership acumen tend to fade with time. 167

In the case of private funds, however, investors are typically locked into the investment for the life of the fund, with few exceptions allowing early redemptions. 168 On the other hand, investors in a public company with a dual-class structure are legally free to sell their positions in highly liquid markets at any time. 169 They can vote with their feet if they no longer believe in the idiosyncratic vision of an entrepreneur-controller. Furthermore, investors in private equity funds do not typically gain the power to replace the asset manager at the end of the fund's life. Instead, they are allowed to withdraw their capital and invest it elsewhere-a

165 Bebchuk \& Kastiel, supra note 113, at 605-06.

$166 \mathrm{Id}$.

167 See Id. at 606. This conclusion is questionable. While it may be true that investors prefer not to place their investment with a particular asset manager for an indefinite period, the life spans of private equity funds may be more related to the expected period required to source investments and achieve improvements in the businesses of the invested companies than to an understanding that the asset manager's ability may fade over time.

168 Addison D. Braendel \& Seth Chertok, Closed-End Private Equity Funds: A Detailed Overview of Fund Business Terms, Part II, 13 J. PRIV. EQUITY 57, 60 (2010).

169 Index funds and asset managers mimicking them are a practical exception, though in terms of their legal rights there are no limits to divestment. See supra note 137 and accompanying text. 
right that investors in public dual-class companies have at all times.

Investors in public dual-class companies also have significantly greater protections than investors in private equity or other investment funds. They are protected by fiduciary duties, generally have a voice in the management of the company (however small it may be), and have access to much more information about the company with which to make informed investment decisions. The managers of private investment funds are able to contract out of their fiduciary duties to fund investors and frequently do. 170 By contrast, the managers and controlling stockholders of public companies, including companies with a dual-class structure, are subject to significant fiduciary duties to minority shareholders as directors, officers, and controlling shareholders. ${ }^{171}$ As public companies with shares registered with the SEC, they also have significantly greater disclosure obligations regarding their results of operations and business trends. ${ }^{172}$ Thus, investors in private equity and venture capital funds have far fewer protections than investors in public dual-class companies, and the lifespans for such funds do not necessarily

170 See Del. Code Ann. tit. 6, § 17-1101(d) (2005) (permitting expansion, restriction, or elimination of fiduciary duties in limited partnerships); Id. $\S$ 18-1101(c) (2005) (same in limited liability companies); Lloyd L. Drury III, Publicly-Held Private Equity Firms and The Rejection of Law as a Governance Device, 16 U. PA. J. Bus. L. 57 (2013); Mohsen Manesh, What is the Practical Importance of Default Rules Under Delaware LLC and LP Law?, HaRv. Bus. L. REV. ONLINE 121, 121-22 (2012); Yves Smith, Presentation Shows Private Equity Investors Knowingly Sign Contracts with Waivers of Fiduciary Duty, Other Terms Stacked Against Them, NAKEDCAPITALISM.COM (Apr., 2 2015), https://www.nakedcapitalism.com /2015/04/presentation-shows-private-equity-investors-knowingly-signcontracts-waivers-fiduciary-duty-terms-stacked.html [https://perma.cc/8ENP-F58D].

171 These obligations are summarized in the American Law Institute's Principles of Corporate Governance. See Principles of Corporate GOVERNANCE: ANALYSIS AND RECOMMENDATIONS, pts. IV \& V (AM. LAW INST. 1994).

172 Compare Regulation S-K, 17 C.F.R. $§ 229$ (2018) with Use of Regulation D, 17 C.F.R. $§ 230.500$ et. seq. (2018). 
justify a similarly limited period of managerial discretion for the entrepreneur-controllers of dual-class companies.

Another argument for time-based sunsets is that entrepreneur-controllers have incentives to retain control even when it would be more economically efficient to unify the capital structure or sell control. Bebchuk and Kastiel explain that because controllers gain only a fraction of the efficiency benefits associated with eliminating inefficient dual-class structures, despite giving up all of their private benefits of control, efficient sales or unifications may not take place in a substantial range of situations in which the entrepreneurcontroller's management of the company has become inefficient. 173 With a smaller fraction of equity capital owned by the controller and a larger amount of the private benefits of control, the controller has an incentive to refuse a wider range of efficient sales or unifications. Bebchuk and Kastiel do not suggest that sales and unifications will never occurtransactions with sufficient value to overcome the controller's disincentives will still occur. The implication, however, is that some inefficient dual-class companies persist in business longer than they should, and steps should be taken to prevent this through time-based sunset provisions. 174

While some inefficient dual-class companies might be eliminated through mandatory time-based sunsets, efficient companies would also be lost. The historical record suggests that such drastic measures are not necessary to encourage the unification or sale of dual-class companies. Only six of nineteen companies included in Jeffrey Gordon's 1988 study ${ }^{175}$ of companies adopting dual-class stock structures as takeover defense mechanisms are still listed. Of those, three have adopted tenure voting, one has collapsed its dual-class structure, and only two remain dual-class companies.176 The

173 Bebchuk \& Kastiel, supra note 113, at 613-18.

174 Bebchuk and Kastiel note that the ISS study cited supra, note 15 concludes that dual-class companies tend to last twice as long as controlled companies with a single class of shares. Id. at 617 .

175 See Gordon, supra note 28.

176 Among the companies in Gordon's study that remain public, only one still has a dual-class stock structure with unequal voting: The Hershey 
remainder have been acquired or gone bankrupt. Similarly, only eight of forty-three companies included in Partch's 1987 study ${ }^{177}$ of firms that adopted dual-class structures between 1961 and 1984 remain listed dual-class companies, most of which are included in this dual-class data set.178

More recently, the founders of several of the companies in the data set have voluntarily collapsed their dual-class stock or sold the company in recent years. The founders of Nu Skin Enterprises, for example, voluntarily converted all of their high vote shares in 2003. The controlling families of Forest City Enterprises and Hubbell Incorporated agreed with investor demands to collapse their dual-class structures. The founders of Apollo Education Group (owner of University of Phoenix), Cablevision, Kayak Software, Molex, and zulily sold their companies between 2013 and 2017.

It is clear companies with dual-class capital structures are not impervious to change. Ronald Gilson explained in 2006 why dual-class share structures fail to persist in intergenerational contexts:

"[p]recisely because non-pecuniary private benefits are idiosyncratic to the particular controlling shareholder and because the identities of controlling shareholders change with generations, it is plausible to expect changes in the value of the non-pecuniary private benefits of control over time ... [a]t some point, the wealth gain from adaptation reflected in a large acquisition premium, or an increase in market value from giving up control and hiring professional

Company. Two companies have converted from dual-class to single-class stock structures: The Gap, Inc. and Lee Enterprises. Three companies, American Family, now AFLAC, Inc., Carlisle Companies Incorporated and The J.M. Smucker Company have a tenure stock structure. See id. at 7985.

177 See Partch, supra note 28.

178 The remaining companies include Bio-Rad Laboratories, Inc., Bowl America Incorporated, The Hershey Company, Kelly Services, Inc., Moog, Inc., A. O. Smith Corporation, Watsco, Inc., and John Wiley \& Sons, Inc. See Partch, supra note 28, at 334-38 tbl.6. 
managers, outweighs the non-pecuniary private benefits of control ...."179

Gilson's final point applies equally to single generation controllers, however. When dual-class controllers conclude that returns from the dual-class structure are no longer attractive - that is, when their visions have run their course and are no longer producing the results the controllers anticipated-they convert their shares to low vote common shares or sell the company.

Finally, in some cases it is possible to persuade a controlling founder to step-down from leadership if that is in the best interests of the company-even if the founder controls elections of the directors. The most high-profile recent example of a controlling founder stepping away from leadership was Travis Kalanick's resignation as the CEO of Uber after being pressured by shareholders to resign. 180

These historic results suggest that it is not necessary to resort to time-based sunsets to terminate dual-class share structures despite controller incentives to avoid sales and unifications. Controllers can be and often are persuaded to unify their capital structures or sell their companies. Since time-based sunsets do not protect the idiosyncratic vision of founders and are not, when other methods are available, necessary to protect investors from economic inefficiencies, they generally will not be part of an optimal dual-class structure.

\section{Dilution and Divestment Sunsets}

Dilution sunsets must be carefully crafted to serve as part of an optimal package of sunset provisions. They could diminish the creation of corporate value by discouraging

179 Gilson, supra note 11, at 1670-71 (predicting that controlling shareholder systems in "good law" countries tend to deteriorate simply from the gravity of generations and providing evidence from Sweden).

180 Katie Benner, Silicon Valley Investors Flexed Their Muscles in Uber Fight, N.Y. TIMES (June 21, 2017), https://www.nytimes.com/2017 /06/21/technology/silicon-valley-investors-flexed-their-muscles-in-uberfight.html [https://perma.cc/472J-YE25]. 
entrepreneur-controllers from issuing additional shares to obtain capital for growth, incentivize new employees, or acquire complementary businesses. 181 As noted supra, Wasserman has documented that entrepreneurs sometimes choose not to take on additional capital in the venture capital stages of growth for fear of losing control of their company. ${ }^{182}$

One of the costs of becoming a controlling shareholder is typically a lower level of investment diversification-the controlling stockholder is typically required to invest a significant percentage of the controller's assets in the controlled corporation-which acts as a natural disincentive to making poor investments of the controlled corporation's assets in a manner that adversely affects the value of the company.

Under the idiosyncratic value theory, the reasons for an entrepreneur's dilution matter. If the entrepreneur's stake is diluted by additional accretive issuances of equity to grow the company and realize the above-market returns inherent in the entrepreneur's vision, the entrepreneur should not be penalized through loss of control. If the entrepreneur is diluted because the entrepreneur is selling interests in the corporation in order to diversify investments, that indicates a lower level of commitment to the idiosyncratic vision embodied by the corporation. Thus, divestment sunsets are a better trigger for high vote conversion than dilution sunsets. When utilized, divestment sunsets should attempt to quantify the point where the entrepreneur's choice to diversify investments through the sale of interests in the company indicates an insufficient remaining commitment to the

181 Banerjee and Masulis have explained that controlling shareholders may forgo positive net present value ("NPV") investments to maintain control unless they benefit from a dual-class share structure. They note that when the NPV of projects that would otherwise have been forgone is higher than the takeover premium that would be available to shareholders in an unimpeded market for control of the corporation, dual-class structures enhance shareholder welfare. Suman Banerjee \& Ronald W. Masulis, Ownership, Investment and Governance: The Costs and Benefits of Dual Class Shares (European Corp. Governance Inst., Working Paper No. 352/2013, 2017).

182 See supra note 142 and accompanying text. 
enterprise. At that point, the entrepreneur should lose control of the company. Alternatively, companies could use formulas to focus on the reasons for dilution and only penalize the entrepreneur-controller for divestment. The Snap charter does this-focusing on the founder's ongoing ownership of high vote shares as a percentage of the number owned at the time of its IPO. ${ }^{183}$

\section{Death and Incapacity Sunsets}

Death and incapacity sunsets should be included in all dual-class charters. The death or incapacity of the founder should collapse the capital structure because the founder is no longer able to pursue an idiosyncratic vision upon death or incapacity. One possible exception is when there are multiple co-founders, where the high vote shares could be transferred to a co-founder, with the capital structure collapsing upon the death or incapacity of the last surviving founder. Another possible exception is when employees imbued with the idiosyncratic vision of the founder and in a position to carry it on hold enough high vote shares to make a material difference in corporate voting going forward. In that case, the employees should arguably be permitted to retain their control block until their own deaths, or as long as they remain employed. The death and incapacity provisions should apply to shares held by permitted transferees of the original shareholders as well as directly by the natural person. This ensures that there are no lingering high vote shares being voted by someone beyond the death or incapacity of the relevant original holder of high vote shares.

One important purpose of death sunsets is to prevent the intergenerational passage of founder control to descendants. Investors in founder-controlled enterprises make an implicit bargain with the founder at the time of the initial public offering that the investors will grant the founder control of the enterprise (subject to certain conditions, or not) in exchange

183 Snap, Inc., Registration Statement (Form S-1) (Feb. 2, 2017), exhibit 3.1, https://www.sec.gov/Archives/edgar/data/1564408/000 119312517029199/d270216dex31.htm[https:/perma.cc/9UKF-MCDG]. 
for an equity stake in the enterprise. Essentially, investors are betting on the founder. They are willing to take the risk that the founder's vision or management abilities may fail because they believe in the founder's vision and capabilities, which is typically demonstrated by the pre-public performance of the company and forecasts for its future performance.

Under purely free market principles, founders should have an opportunity to offer investors shares in a company that permits intergenerational transfers of control, and investors can be held to that bargain when the founder dies. The founder is conditioning participation in the above-market returns produced by the founder's enterprise on acceptance of the founder's descendants managing the company after the founder's death. But that bargain is not justified by the need to protect the pursuit of the founder's vision for corporate value. Instead, from a macroeconomic perspective, the bargain may lead to an unfortunate waste of economic resources. Each generation of individuals is likely to have different visions and capabilities. Studies have suggested that the performance benefits of founder control recede in succeeding generations. ${ }^{184}$ While it is conceivable that new generations of the founding family, or managers and employees who have worked with the founder for many years, would have the same or similar idiosyncratic vision as the founder, when investing in a founder-led company, investors are investing in the vision of the founder and, sometimes, her

184 Morten Bennedsen, Kasper Meisner Nielsen, Francisco PerezGonzalez \& Daniel Wolfenzon, Inside the Family Firm: The Role of Families in Succession Decisions and Performance, 122 Q.J. ECON. 647, 669-670, 684 (2007); Gilson, supra note 11, at 1661, 1668; Kastiel, supra note 140, at 118; Randall Morck, Andrew Shleifer \& Robert W. Vishny, Management Ownership and Market Valuation, 20 J. FIN. ECON. 293, 311 (1988) (concluding that performance of older firms is worse when the firm is run by a member of the founding family); Belen Villalonga \& Raphael Amit, How Do Family Ownership, Control and Management Affect Firm Value?, 80 J. Fin. ECON. 385, 399-400 (2006); Randall Morck, Daniel Wolfenzon \& Bernard Yeung, Corporate Governance, Economic Entrenchment and Growth 16 (Nat'l Bureau of Econ. Research, Working Paper No. 10692, 2004), https://www.nber.org/papers/w10692.pdf [https://perma.cc/4Z2ZT694]. 
management acumen. The situation is even more egregious when the controlling holder is no longer an officer or director of the company but seeks to pass control of the company to a family member or a favored successor. This situation arose recently with Viacom, when Sumner Redstone sought to pass control of the company to his daughter. ${ }^{185}$

To avoid issues with inheritance of control, investors should have an opportunity to vote on whether to extend control benefits to a different generation of the founding family or another group of individuals to whom the founder might consider transferring control. This will essentially allow investors to make a bet on a new individual or group of managers. In order to allow investors the right to make this choice, dual-class companies should consider including death and incapacity provisions in their charters in the future.

\section{Separation Sunsets}

Separation sunsets should also be included in all dual-class charters. Separation sunsets were included in the amendments to the Facebook charter in connection with its proposed introduction of non-voting Class $\mathrm{C}$ common shares. Separation sunsets are consistent with the Goshen and Hamdani model of corporate governance: once the founder is no longer actively involved in the management of the company as an officer or director, the founder cannot reasonably claim to be involved in pursuing the idiosyncratic vision for creating corporate value that justified the establishment of the dualclass share structure. The definition of "cause" for purposes of the termination clause of the separation sunset should not establish a bar that is too high to constitute an effective trigger upon the termination of the entrepreneur-controller as an executive officer.

In industries where conviction of a felony would disqualify a person from acting as an executive officer of a company, sunset provisions should reflect that by making the high vote

185 Keach Hagey, Shari Redstone's Path to Power, WALL ST. J. (June 22, 2018, 5:32 AM), https://www.wsj.com/articles/shari-redstones-path-topower-1529659921 (on file with the Columbia Business Law Review). 
shares convert to low vote shares upon an entrepreneurcontroller's final conviction of a disqualifying felony.

\section{Transfer Sunsets}

High vote shares should convert on virtually any transfer, with the exception of transfers for tax and estate planning purposes. Transfer of high vote shares is inconsistent with the creation of such shares to support an entrepreneur's pursuit of an idiosyncratic vision. The vision in which shareholders invest is not that of a third-party transferee. Nor is it necessary to permit transfers to family members or dynastic control to support an entrepreneur's pursuit of a value enhancing idiosyncratic vision. Transfers to family members, other high vote shareholders, and entities not exclusively owned by the transferor should lead to conversion of the high vote shares. Statistical studies have shown that familycontrolled firms controlled by heirs as opposed to the founders themselves typically experience a decline in firm performance. 186

The permitted entity transfers provision should follow the Facebook model, which requires exclusive ownership of the relevant entity by the transferor. The Google model, permitting transfer when the transferor retains voting and dispositive control of the high vote shares, permits sharing the benefit of the high vote shares with parties other than the founder-which is not necessary to support the founder's pursuit of her vision. The trusts provision should, however, follow the Google approach. Charters should specify particular types of trusts and require voting and dispositive control to remain in the hands of the founder. This approach contrasts with the Facebook approach, which permits transfers to trusts for which professional trustees or family members may act as trustees of the trust, with no reference to retained voting and dispositive control by the founder.

Transfer conversion provisions permitting transfers by stockholders that are partnerships and LLCs to their partners or members, as the case may be, are also not necessary to 
support a founder's ability to pursue the idiosyncratic value of control and should not be included. Venture capital funds and other pre-IPO investors should not receive high vote shares in connection with the IPO in any event, unless they continue to be actively involved in the enterprise through representation on the board of directors of the company, making them accountable to public investors. However, transfers to cofounders are consistent with the pursuit of an idiosyncratic vision and should be permitted.

\section{Performance Sunsets}

As discussed previously, the most challenging aspect of the theory of idiosyncratic value is that it gives investors little opportunity to avoid the agency costs inherent in poor business decisions. Goshen and Hamdani are unbending in advocating that entrepreneur-controllers should be granted a property right in their idiosyncratic vision. ${ }^{187}$ This means that investors may not fire the entrepreneur-controller as manager of the corporation even if the idiosyncratic vision leads the entrepreneur-controller to make poor business decisions that destroy value.

One way to potentially address the gap between the expectations of entrepreneur-controllers and investors would be to establish dual-class sunset provisions focused on performance measures. A wide variety of performance measures could be imagined. The ideal performance sunset would focus on a standard under which even the most determined entrepreneur-controller would admit that an idiosyncratic vision for value creation has clearly failed. A sunset might trigger, for example, if revenue, income, or the stock price of the company falls below the levels at the time of the initial public offering for a significant period of timeperhaps two or three years. Investors should be prepared to be flexible in thinking about performance sunset measures, however, as some idiosyncratic visions may take years to incubate before they start to succeed. If the parties consider measures on a company-by-company basis, rather than seek a

187 See Goshen \& Hamdani, supra note 12, at 601-03. 
one-size-fits-all solution, performance sunsets are a workable solution to the entrepreneur-investor control conundrum.

The challenge with performance sunsets is that the entrepreneur-controller acting as manager will have to manage the performance of the company in a manner that successfully survives the performance tests. This challenge is similar to how managers of public companies with dispersed ownership engage in earnings management to achieve performance goals tied to compensation and in connection with insider trading windows. 188 Thus, performance sunsets, if used, must be carefully designed in order to avoid gaming.

\section{Fiduciary Sunsets}

Another option that investors concerned about agency costs can consider is a fiduciary sunset. The concept of a fiduciary sunset is simple: if entrepreneur-controllers are found to have breached their fiduciary duties to shareholders as officers, directors, or controlling shareholders of the company, in a manner that is not indemnifiable, consequences should impact their control of the corporation. In the context of a company with a single class of stock and dispersed ownership, such a fiduciary breach by an officer or director would typically lead to termination, resignation, or removal from office by the shareholders. 189 In the context of a dual-

188 See Christopher S. Armstrong, David F. Larcker, Gaizka Ormazabal \& Daniel J. Taylor, The Relation Between Equity Incentives and Misreporting: The Role of Risk-Taking Incentives, 109 J. Fin. Econ. 327, 327 (2013); Michael C. Jensen, Kevin J. Murphy \& Eric G. Wruck, Remuneration: Where We've Been, How We Got to Here, What Are the Problems, and How to Fix Them 89 (Harvard Bus. Sch. NOM, Working Paper No. 04-28, 2004), https://ssrn.com/abstract=561305 [https://perma.cc/9T6W-ZZGP]; John Bizjak, Rachel M. Hayes \& Swaminathan L. Kalpathy, Performance-Contingent Executive Compensation and Managerial Behavior 5 (Dec. 10, 2015) (unpublished manuscript), https://ssrn.com/abstract=2519246 [https://perma.cc/3HGAZA3X].

189 Ideally, a fiduciary sunset would also cover the obligations of the entrepreneur-controller to the public investors as a controlling shareholder. There have been several judicial actions where shareholders have successfully challenged the control group in a dual-class company. See e.g., 
class company, the entrepreneur-controller is shielded from that result. 190 To make the dual-class structure more palatable to institutional investors and other public stockholders, entrepreneurs wishing to establish a dual-class structure might consider incorporating consequences for breach of fiduciary duties that impact the entrepreneurcontroller's control of the corporation. Shareholder concerns about control agency risk, and to some extent management agency risk, might be ameliorated by such a provision. If the entrepreneur-controller is held to have breached a duty of care, some kind of sunset of control can kick in. These controls can be either a limit to the term of the dual-class structure, or a sharing of control. For example, the sunset might cause some matters to become subject to minority investor approval.

\section{Additional Protections for Dual-Class Investors}

Sunset provisions may ultimately be insufficient to protect investors from the risks of agency costs associated with dualclass share structures. In addition to sunsets, there are other provisions entrepreneur-controllers can incorporate into dual-class corporate charters to offer public investors additional protection against agency costs without accepting the wholesale transfer of control implicated by time-based sunset provisions. Among the measures entrepreneurcontrollers can consider offering (and investors can consider seeking) are (1) pro rata distribution of consideration upon a change of control, (2) a promise to compensate low vote shareholders for any charter amendments changing the corporate governance structure post-IPO or otherwise

Stephen I. Glover \& Aarthy S. Thamodaran, Debating the Pros and Cons of Dual-Class Capital Structures, Insights, Mar. 2013, at 6. (citing Levco Alternative Fund Ltd. v. Reader's Digest Ass'n, Inc., 803 A.2d 428 (Del. 2002); In re Delphi Fin. Grp. S'holder Litig., C.A. No. 7144-VCG, 2012 WL 729232, at*14 (Del. Ch. Mar. 6, 2012)).

190 While controlling shareholders are not typically subject to termination or a loss of control in connection with a breach of fiduciary duties to the minority, that still might be a rational resolution to the tension between the entrepreneur's and investors' competing desires for control of the company. 
adversely affecting the rights of the low vote investors, and (3) power-sharing arrangements, which might, for example, (a) limit high vote power to certain major corporate decisionssuch as the election of directors and sale of the corporationor (b) empower low vote shareholders to vote on equal terms with the high vote holders on certain corporate matters, such as executive compensation.

\section{Pro Rata Distribution of Change-of-Control Consideration}

One significant concern for public investors in controlled companies is the prospect of a sale of control or a sale of the company creating an uneven distribution of the value of the company to the entrepreneur-controller. Control premiums have been described as a proxy for private benefits of control or even as a proxy for minority expropriation. 191 While strict transfer conversion sunset provisions can effectively prevent a sale of a control position in a dual-class company, they cannot prevent private bargaining for separate and better consideration in a sale of the company by an entrepreneurcontroller. Goshen and Hamdani suggest that entrepreneurcontrollers are often willing to share the benefits of value created through the pursuit of their idiosyncratic visions with outside investors pro rata.192 The understanding that all investors will benefit pro rata from the proceeds of any sale of the corporation can become part of the explicit bargain between entrepreneur-controller and public investors at the time of the IPO through charter provisions stating that all classes of stock will share equally, pro rata, in the proceeds of any sale. Alphabet and other companies already have such a provision in their charter.193 Both Kevin Plank of Under

191 See e.g., Lucian Arye Bebchuk, Efficient and Inefficient Sales of Corporate Control, 109 Q.J. ECON. 957, 959-60 (1994).

192 See Goshen \& Hamdani, supra note 12, at 567, 572-73, 576.

193 In addition to Alphabet, other companies with a merger equity provision include Ameresco, Duluth Holdings, Estee Lauder, FitBit, Groupon, LinkedIn, MaxLinear, MINDBODY, NCI, News Corp, Nu Skin, Ralph Lauren, Reata Pharmaceuticals, Skechers, Square, Tableau Software, Trade Desk, Twilio, Under Armour, Wayfair, Workiva, Yelp, and 
Armor and Mark Zuckerberg of Facebook accepted charter amendments requiring them to give up control premiums in connection with the introduction of no vote stock into the companies' capital structures as a means of perpetuating their control of their companies. 194

\section{Compensation for Charter Alterations}

Goshen and Hamdani argue that entrepreneur-controllers should not be permitted to take advantage of their control positions to alter corporate governance structures to their advantage after an initial bargain over governance is struck in connection with the initial investment in the entrepreneurcontrollers' enterprises. 195 Public investors in low vote shares should be protected from such (essentially self-dealing) alterations of the implied contract. They argue, however, that minority protection should not take the form of an ex ante approval right, but rather, an ex-post judicial review of such transactions for fairness to public investors. Otherwise, holdouts can interfere with the entrepreneur-controller's management rights. The ex-post requirement of fair compensation can, however, be incorporated into the charter ex ante rather than relying on the varying review standards of judicial monitoring.

As noted by Goshen and Hamdani, in the past, Delaware courts have not required shareholders be compensated for charter amendments, as long as the changes affect all

Zynga. Andrew William Winden, Dual-Class Data Set (on file with the Columbia Business Law Review).

194 Facebook, Inc., Proxy Statement (Schedule 14A), at 67 (June 2, 2016), https://www.sec.gov/Archives/edgar/data/1326801/000132680116 000074/facebook2016definitiveprox.htm [https://perma.cc/X5SR-62VP]; Under Armour, Inc., Proxy Statement (Schedule 14A), at 8 (July 13, 2015), https:/www.sec.gov/Archives/edgar/data/1336917/000119312515251272/d9 31136ddef14a.htm [https://perma.cc/F42X-3XC3].

195 See Goshen \& Hamdani, supra note 12, at 608-09 ("A necessary element in any minority-protection scheme is, therefore, a protection against unilateral, midstream changes to the firm's governance arrangement"); see also Paul Lee, Note, Protecting the Public Shareholders: The Case of Google's Recapitalization, 5 HARV. Bus. L. REV. 281, 292-93 (2015). 
shareholders equally from a legal perspective. ${ }^{196}$ Entrenching effects have not provided a cause for compensation. The leading case is Williams $v$. Geier, in which the Delaware Supreme Court held that a controlling shareholder's vote to change the charter to impose a tenure voting system was not self-dealing and did not require application of the entire fairness doctrine. 197 It is possible the Williams case, which is now twenty years old, would be decided differently if reviewed today-imposing an entire fairness standard of review for charter amendments entrenching a controlling shareholder. In any event, Goshen and Hamdani argue that investors should be protected from efforts by a controller to change the mix of control and cash-flow rights mid-stream because an initial public offering of minority voting equity to the public established an implicit agreement regarding such rights at that point in time. ${ }^{198}$

Two recent mid-course changes have resulted in compensation to shareholders. The founders of both Google and Under Armor, after approving charter amendments to introduce new classes of non-voting common stock in order to preserve their voting control following additional issuances of equity, agreed that their company would compensate the owners of the new non-voting class for the difference between the market price of the non-voting shares and the market price of the voting shares. 199 Google paid such shareholders

196 Goshen \& Hamdani, supra note 12, at 609.

197 Williams v. Geier, 671 A.2d 1368, 1371 (Del. 1996).

198 Goshen \& Hamdani, supra note 12, at 609.

199 Google, Inc., Current Report (Form 8-K), exhibit 99.1 at 7 (Oct. 30, 2013), https://www.sec.gov/Archives/edgar/data/1288776/00011931251341 8880/d618226dex991.htm [https://perma.cc/LRD7-4AVE]; Under Armour, Inc., Current Report (Form 8-K) (Oct. 7, 2015), https://www.sec.gov/Archives/edgar/data/1336917/000133691715000040/oc tober72015form8-k.htm [https://perma.cc/7LYK-QHBK]; Under Armour, Inc., Current Report (Form 8-K) (June 16, 2016), https://www.sec.gov/Archives/edgar/data/1336917/000133691716000091/ju ne162016form8-k.htm [https://perma.cc/6DJB-WCC5]. 
approximately $\$ 522$ million as a result. 200 Zillow introduced non-voting common shares in connection with charter amendments to accommodate its acquisition of Trulia in 2015 and did not face a class action in connection with its charter changes. $^{201}$ Under Goshen and Hamdani's rubric, if such charter changes had the effect of allowing Zillow's founders to control more of the votes with less of the cash flow rights, the founders (not Zillow) should have compensated the other shareholders for the change.

In accepting Google's settlement of class action litigation regarding the introduction of its non-voting shares, then Chancellor Strine expressed skepticism about the fact that the compensation was to be paid by the company, rather than by the founders, the presumptive beneficiaries of the charter amendments. 202 Strine was also skeptical of the fact that the compensation would be paid by the company to all holders of the non-voting shares, including the controlling founders. 203 The founders and directors of Facebook and IAC/Interactive faced class action lawsuits after similarly approving charter amendments to introduce new classes of non-voting common stock-in order to perpetuate the founder's control while issuing additional equity (or, in Facebook's case, while divesting a portion of the founder's cash flow rights) - and ultimately had to abandon their efforts. 204 Given now-Chief

200 Google, Inc., Current Report (Form 8-K), exhibit 99.1 at 3 (Apr. 23, 2015), https://www.sec.gov/Archives/edgar/data/1288776/000128877615 000021/googq12015exhibit991.htm [https://perma.cc/PMU3-F5R5].

201 Zillow Group, Inc., Registration Statement (Form S-4), at F-1-14

(Sept. 12, 2014), https://www.sec.gov/Archives/edgar/data/1617640/ 000119312514339427/d778624ds4.htm\#toc778624_138 [https://perma.cc/ZT43-J7KV].

202 Settlement Hearing and Rulings on the Court at 2-4, In Re Google Inc. Class C S'holder Litig., No. 7469-CS, 2013 WL 6735045 (Del. Ch. Oct. $28,2013)$.

$203 \mathrm{Id}$.

204 Queenie Wong, Facebook Drops Stock Plan that Would Have Allowed Zuckerberg to Maintain Control, MERCURY News.COM (Sept. 22, 2017, 5:17 PM), https://www.mercurynews.com/2017/09/22/facebook-dropsstock-plan-that-would-have-allowed-zuckerberg-to-maintain-control/ [https://perma.cc/Q893-X237]; Press Release, CalPERS, In Response to 
Justice Strine's skepticism about the absence of compensation from the controllers to the minority shareholders in the Google case, it will be interesting to see what, if any, settlement terms emerge from those cases, or how the Delaware courts resolve the disputes going forward. In any event, for present purposes, it is sufficient to note that the charters of dual-class companies can include a provision requiring controlling shareholder compensation of minority shareholders for adverse changes to the terms of the charter. As noted above, a more typical provision requiring minority shareholder approval would not be consistent with Goshen and Hamdani's view that solutions to minority shareholder concerns should not interfere, ex ante, with the controller's right to control the company.

Of course, the opposite should also be true; where investors prevail upon controlling founders to collapse a dual-class system into a single class of equal voting shares, the controller should be compensated. Studies and experience have shown that where both high and low vote (or low and no vote) shares of an issuer are listed, the low (or no) vote shares typically trade at a three to five percent discount to the price of the higher voting shares. 205 The no vote shares of Alphabet, Inc. have traded at such a discount to the low vote shares of Alphabet since they were listed in 2013. ${ }^{206}$ We can assume, therefore, that a discount is incorporated into the price of low

CalPERS Lawsuit, IAC Abandons Plan to Issue Non-Voting Stock (June 23, 2017), https://www.calpers.ca.gov/page/newsroom/calpers-news/2017 /interactivecorp-abandons-plan-non-voting-stock [https://perma.cc/PU2M5PEB].

205 Dan Caplinger, What the Google Stock Split Taught Investors About Corporate Governance, Motley Fool (Sept. 1, 2016, 5:33 PM), https://www.fool.com/investing/2016/09/01/what-the-google-stock-splittaught-investors-about.aspx [https://perma.cc/7PV4-PB9N]; Aaron Stumpf \& Andrew Cline, Price Differentials Between Voting and Nonvoting Stock, STOUT, https://www.stoutadvisory.com/insights/article/price-differentialsbetween-voting-and-nonvoting-stock [https://perma.cc/49G9-8U9K].

206 Jesse Emspak, GOOG or GOOGL: Which Stock Do You Buy?, INVESTOPEDIA (June 28, 2018, 6:00 AM), https://www.investopedia.com/ articles/markets/052215/goog-or-googl-which-google-should-you-buy.asp [https://perma.cc/VTL9-F5NM]. 
vote shares of a dual-class company listed at the time of its initial public offering. That is, public investors benefit from a lower initial price, while founders settle for a lower price for the shares of their companies than they could obtain if they did not retain control through a dual-class structure. ${ }^{207}$

When institutional investors insist that the boards of dualclass companies establish time-based sunset provisions to phase out the structure over time so they will have equal voting rights in the future, they should understand that they are asking for a right they have not paid for. Such shareholders should arguably pay a premium to the company in connection with receiving equal voting rights in such situations. In practice, low vote shareholders have not typically paid companies for additional voting rights in connection with dual-class reclassifications, but in some cases, holders of high vote shares have, appropriately, been compensated for their loss of control. For example, when Hubbell Inc. reclassified its shares into a single class of voting common in 2015, high vote shareholders received a special dividend of $\$ 200$ million. 208 When Forest City Enterprises collapsed its dual-class structure in 2017, the high vote shareholders received a thirty-one percent premium (in

207 When institutional investors say, with respect to high performing dual-class companies, that they should have equal voting shares just in case things go bad in the future, they are essentially suggesting that the market is not properly pricing the risk that such management failures could occur in the future. This is an odd result given the extent to which other risks, such as the risk of bankruptcy, are perceived to be accurately priced into the market values of securities, including high yield bonds. If investors believe the risk of poor management performance in the future is not properly reflected in the share price of a dual-class company, they ought to short the shares.

208 Hubbell Inc., Current Report (Form 8-K) exhibit 99.1 at 2 (Aug. 24, 2015), https://www.sec.gov/Archives/edgar/data/48898/ 000119312515299447/d26695dex991.htm [https://perma.cc/PW2W-7BCD]; Hubbell Inc., Current Report (Form 8-K) (Dec. 23, 2015), https:/www.sec.gov/Archives/edgar/data/48898/000119312515412174/d110 573d8k.htm [https://perma.cc/5W3G-DXWX]. 
common shares) on their high vote shares upon conversion. 209 In both of these cases, the compensation was provided by the company rather than other shareholders. 210

\section{Selective Power Sharing: Majority of the Minority Votes}

Entrepreneur-controllers could agree to obtain majority-ofthe-minority votes with respect to corporate decisions otherwise reserved to the managers or the board, in much the same way as venture investors holding preferred shares are often given voting power with respect to significant corporate decisions. This would give the entrepreneur-controller day-today management discretion of the company while giving investors some levers to protect their interests. The compensation of executives is one matter as to which shareholders are already required to be given a non-binding vote. Their vote could be made binding. There may be other areas in which power-sharing could be considered, such as incurrence of debt over certain amounts, acquisitions over a certain value, or other significant corporate decisions.

\section{VIII.CONCLUSION}

There is a fundamental tension, or tradeoff, between entrepreneurs' freedom to pursue idiosyncratic visions for value creation and investors' need for protection from agency costs. This tension is particularly acute in the context of dualclass companies, where the entrepreneur's uncontestable and indefinite control, coupled with the entrepreneur's smaller equity interest, leaves investors with comparatively high exposure to agency costs. It is not surprising, then, that institutional investors have responded to recent increases in the number of dual-class IPOs with calls for prohibition,

209 Forest City Realty Tr., Inc., Current Report (Form 8-K) exhibit 3.1 at 7 (June 12, 2017), https://www.sec.gov/Archives/edgar/data/1647509/ 000119312517201428/d411995dex31.htm [https://perma.cc/M2MP-RXJS].

210 Arguably, low vote shareholders should be paying high vote shareholders directly for the acquisition of control rights. 
termination or strict limitation, while entrepreneurs and their lawyers insist on maintaining the private ordering status quo.

A thorough review of the terms of dual-class stock structures reveals that the tension between entrepreneurs and institutional investors over control of emerging companies can be resolved through careful drafting of corporate charters to reflect the fundamental bargain between the parties - money for vision-and the interests underlying their respective bids for control: security from interference or dismissal for the entrepreneur and opportunity for voice and influence for investors. When the terms of dual-class share structures are considered in detail, we can identify creative ways to give entrepreneurs the control they seek-for as long as they want it, in a manner that does not compromise accountability-and incentivize careful stewardship of corporate assets. Given the diversity among entrepreneurs and companies in terms of vision, execution, industry, and competition, this is not a one-size-fits-all exercise. While in some cases it should be possible to negotiate a set of sunset provisions that satisfy investor concerns, in other cases it may be necessary to resort to sunrise provisions that enhance investor influence, such as a public investor right to nominate and elect a minority of the board of directors.

As noted in Part V, law firms advising companies pursuing initial public offerings have tremendous influence in determining the terms of dual-class stock structures. If, as suggested by Wilson Sonsini Goodrich \& Rosati's response to institutional investor calls for prohibition or strict limitation of dual-class stock structures, such firms wish to preserve the current system of private ordering in designing such stock structures, they have a responsibility to be more creative and proactive in designing structures that respond more effectively to investors' concerns while retaining founders' ability to pursue their visions for value creation without undue interference or dismissal. As explained in Part VII, there are many different ways to approach that effort. 


\section{APPENDIX}

\section{A. Dual-Class Data Set Companies Listed by Dual- Class Adoption or Listing Year}

$\underline{2017}$

ACM Research, Inc.

Altair Engineering, Inc.

Alteryx, Inc.

Appian Corp.

Bandwidth, Inc.

Blue Apron Holdings, Inc.

CarGurus, Inc.

Carvana Co.

Hamilton Lane, Inc.

Laureate Education, Inc.

MuleSoft, Inc.

Newmark Group, Inc.

Okta, Inc.

Roku, Inc.

Schneider National, Inc.

Snap, Inc.

Stitch Fix, Inc.

\section{$\underline{2015}$}

Appfolio, Inc.

Box, Inc.

Duluth Holdings, Inc.

First Data Corp.

Fitbit, Inc.

Houlihan Lokey, Inc. Inovalon Holdings, Inc. MINDBODY, Inc.

Pure Storage, Inc.

RMR Group, Inc.

Square, Inc.

Summit Materials, Inc.

Virtu Financial, Inc.

\section{6}

Apptio, Inc.

CommerceHub, Inc.

Nutanix, Inc.

Reata Pharmaceuticals, Inc.

Red Rock Resorts, Inc.

SecureWorks Corp.

Trade Desk, Inc.

Twilio, Inc.

\section{$\underline{2014}$}

Castlight Health, Inc.

Fifth Street Asset

Management, Inc.

GoPro, Inc.

Medley Management, Inc.

Moelis \& Company

Phibro Animal Health Corp.

Wayfair, Inc.

Workiva, Inc. 
$\underline{2013}$

Coty, Inc.

Fairway Group Holdings Corp.

News Corp.

(Spin-off from old News Corp.)

Re/Max Holdings, Inc.

RingCentral, Inc.

Tableau Software, Inc.

Veeva Systems, Inc.

William Lyon Homes

zulily, Inc.

(Acquired in 2015)

\section{$\underline{2011}$}

AMC Networks, Inc. (Spin-off from Cablevision)

Groupon, Inc.

(Sunset in 2016)

LinkedIn Corp.

TripAdvisor, Inc.

Zillow Group, Inc.

(Initially Zillow, Inc.)

Zynga, Inc.

$\underline{2009}$

Hyatt Hotels Corporation

$\underline{2007}$

Pzena Investment

Management, Inc.

EchoStar Corporation

$\underline{2005}$

Dolby Laboratories, Inc.

DSW, Inc. $\underline{2012}$

Facebook, Inc.

Globus Medical, Inc.

Kayak Software, Inc.

(Acquired in 2013)

Tilly's Inc.

Workday, Inc.

Yelp, Inc. $\underline{2010}$

Ameresco, Inc.

Ironwood Pharmaceuticals,

Inc.

Madison Square Garden Co.,

The

(Spin-off from Cablevision)

MaxLinear, Inc.

(Sunset in 2017)

Swift Transportation Company

\section{$\underline{2008}$}

Discovery Communications,

Inc.

Scripps Networks Interactive, Inc.

\section{$\underline{2006}$}

Spirit Aerosystems Holdings, Inc.

\section{$\underline{2004}$}

Alphabet, Inc.

(initially Google, Inc.) 
Molson Coors Brewing Co.

NCI, Inc.

Under Armour, Inc.

Viacom, Inc.

(Spin-off from

Corporation)

\section{$\underline{2003}$}

Nelnet, Inc.

Nexstar Media Group, Inc.

$\underline{2001}$

Expedia, Inc.

(IPO 1999)

\section{$\underline{1998}$}

Broadcom Corp.

Federated Investors, Inc.

$\underline{1996}$

Genesee \& Wyoming, Inc. IAC/InterActive Corp.

(Listed in 1992)

Lamar Advertising Co.

Lennar Corp.

$\mathrm{Nu}$ Skin Enterprises, Inc.

\section{$\underline{1994}$}

Apollo Education Group, Inc. (Acquired in 2016)

Erie Indemnity Co.

\section{$\underline{1987}$}

Rockwell Automation (Sunset in 1997)

Tootsie Roll Industries (Listed in 1922)
DreamWorks Animation SKG, Inc.

Marchex, Inc.

Texas Roadhouse, Inc. CBS (Sunset in 2009)

Twenty-First Century Fox, Inc. (Initially incorporated as News Corp.)

\section{$\underline{2002}$}

Dick's Sporting Goods, Inc. ManTech International Corp. Regal Entertainment Group

\section{$\underline{1999}$}

Skechers U.S.A., Inc.

United Parcel Service, Inc.

$\underline{1997}$

Ralph Lauren Corp.

$\underline{1995}$

Boston Beer, Inc., The

DISH Networks, Inc.

Estee Lauder Companies Inc.,

The

MSC Industrial Direct Co., Inc.

\section{$\underline{1991}$}

Panera Bread Co.

Regeneron Pharmaceuticals, Inc.

\section{$\underline{1986}$}

Cablevision Systems Corp. (Acquired in 2016)

CBS Corp.

(Initially, Viacom, Inc.) 
Meredith Corporation

(Listed in 1978)

\section{4}

Vishay Intertechnology, Inc.

Watsco, Inc.

\section{$\underline{1982}$}

John Wiley \& Sons

(Listed in 1962)

$\underline{1981}$

Telephone \& Data Systems, Inc.

\section{$\underline{1978}$}

Brown-Forman Corp.

Forest City Enterprises, Inc.

(Converted to Forest City

Realty Trust in 2016; converted to single class in 2017)

Hershey Co., The

Tyson Foods, Inc.

$\underline{1972}$

Comcast Corp.

Molex, Inc.

(Acquired in 2013)

$\underline{1967}$

New York Times Co.

$\underline{1956}$

Ford Motor Co. $\underline{1983}$

A.O. Smith Corporation

\section{$\underline{1980}$}

Bio-Rad Laboratories, Inc. (Listed in 1966)

Nike, Inc.

Universal Health Services, Inc.

\section{9}

Eaton Vance

$\underline{1973}$

Constellation Brands, Inc.
1971

Graham Holdings Co.

(IPO as Washington Post Company)

\section{0}

HEICO Corp.

1936

Hubbell, Inc.

(Reclassified to single class in 2015) 
B. Time-based, Dilution and Divestment Sunsets

\begin{tabular}{|c|c|c|c|c|c|c|c|}
\hline $\begin{array}{l}\text { Year of } \\
\text { listing }\end{array}$ & $\begin{array}{c}\text { No } \\
\text { Sunsets }\end{array}$ & $\begin{array}{c}\text { Time- } \\
\text { based } \\
\text { Sunset }\end{array}$ & $\begin{array}{c}\text { Dilution } \\
\text { Sunset }\end{array}$ & $\begin{array}{c}\text { Divestment } \\
\text { Sunset }\end{array}$ & $\begin{array}{l}\text { Time- } \\
\text { based } \\
\text { and } \\
\text { Dilution }\end{array}$ & $\begin{array}{c}\text { Time-based } \\
\text { and } \\
\text { Divestment }\end{array}$ & Total \\
\hline $\begin{array}{l}1999 \text { and } \\
\text { earlier }\end{array}$ & 28 & & 8 & 7 & & 1 & 44 \\
\hline 2000 & & & & & & & \\
\hline 2001 & 1 & & & & & & 1 \\
\hline 2002 & 2 & & & 1 & & & 3 \\
\hline 2003 & & & 1 & 1 & & & 2 \\
\hline 2004 & 4 & & & & 1 & & 5 \\
\hline 2005 & 5 & & 1 & & & & 6 \\
\hline 2006 & & & 1 & & & & 1 \\
\hline 2007 & 1 & & 1 & & & & 2 \\
\hline 2008 & 2 & & & & & & 2 \\
\hline 2009 & & & 1 & & & & 1 \\
\hline 2010 & 2 & 1 & & 1 & 1 & & 5 \\
\hline 2011 & 3 & 1 & 2 & & & & 6 \\
\hline 2012 & 1 & 1 & 2 & & 2 & & 6 \\
\hline 2013 & 3 & 2 & 1 & 2 & 1 & & 9 \\
\hline 2014 & 2 & & 4 & 1 & & 1 & 8 \\
\hline 2015 & 3 & 2 & 7 & & 1 & & 13 \\
\hline 2016 & 2 & 1 & 2 & 1 & 1 & 1 & 8 \\
\hline 2017 & 3 & 2 & 5 & 2 & 5 & & 17 \\
\hline Total & $\underline{62}$ & $\underline{10}$ & $\underline{36}$ & $\underline{16}$ & $\underline{12}$ & $\underline{3}$ & $\underline{139}$ \\
\hline
\end{tabular}


C. Death and Incapacity Sunsets

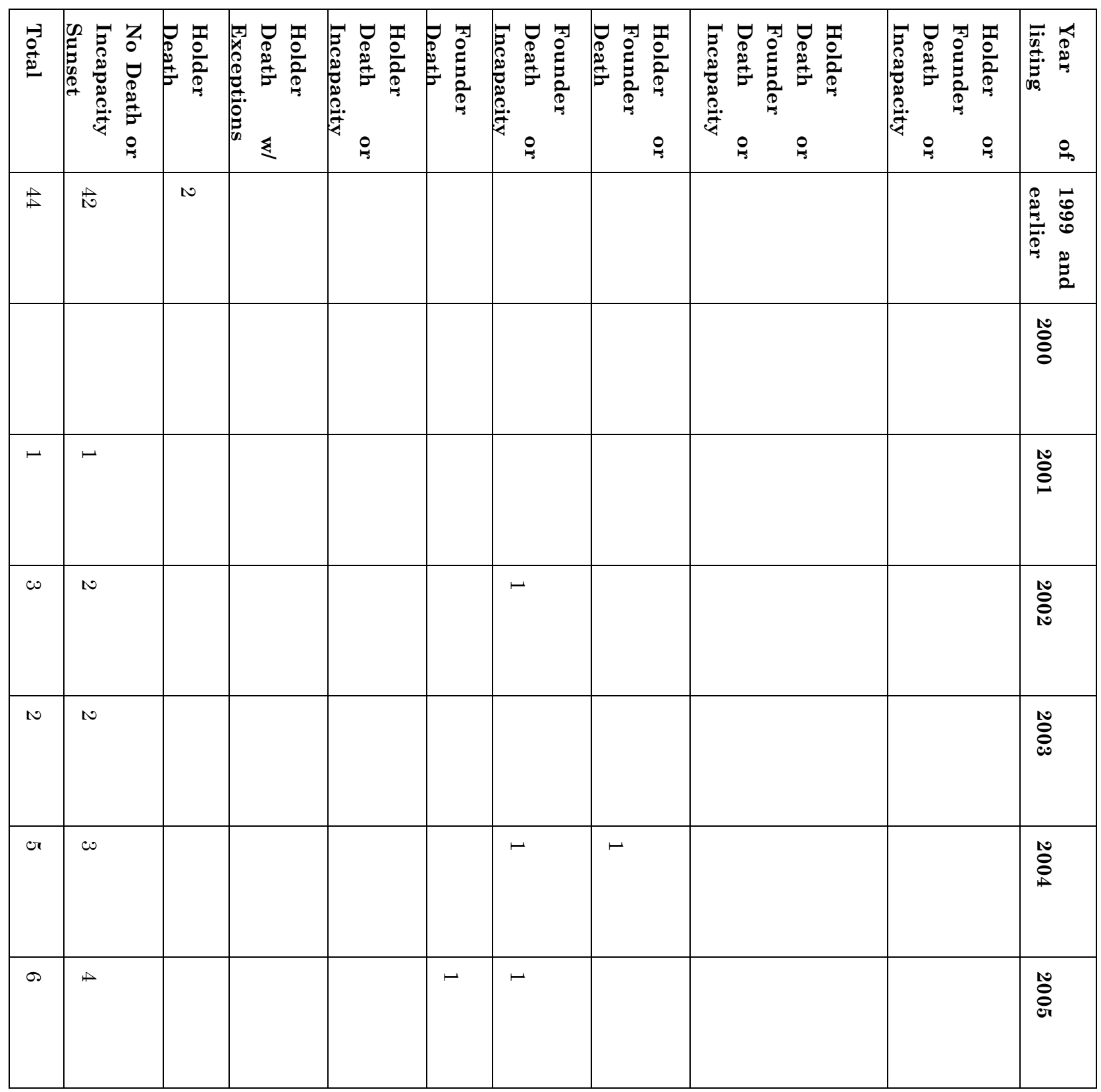


No. 3:852]

\begin{tabular}{|c|c|c|c|c|c|c|c|c|c|}
\hline$r$ & $r$ & & & & & & & & $\stackrel{0}{0}$ \\
\hline$N$ & $N$ & & & & & & & & \& \\
\hline$N$ & N & & & & & & & & $\stackrel{ }{8}$ \\
\hline 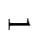 & $r$ & & & & & & & & 응 \\
\hline or & $\omega$ & $\vec{\Xi}$ & $r$ & & & & & & $\stackrel{\text { }}{\stackrel{0}{0}}$ \\
\hline$\sigma$ & $N$ & & & $\vec{E}$ & & $r$ & & $\stackrel{N}{E}$ & $\stackrel{\text { }}{\stackrel{\theta}{\theta}}$ \\
\hline$\sigma$ & 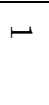 & $\vec{\Xi}$ & & $\vec{\Xi}$ & $r$ & $r$ & & $\vec{\Xi}$ & 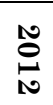 \\
\hline 0 & $\omega$ & & & $\mathbb{N}$ & $r$ & & - & N & $\underset{\mathscr{c}}{\stackrel{N}{0}}$ \\
\hline$\infty$ & or & & $N$ & & $r$ & & & & $\stackrel{\circ}{0}$ \\
\hline
\end{tabular}




\begin{tabular}{|c|c|c|c|c|c|c|c|c|c|c|}
\hline$\vec{\omega}$ & $\checkmark$ & & $N$ & $\vec{\Xi}$ & & & $\vec{\Xi}$ & & $\stackrel{N}{\Theta}$ & 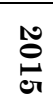 \\
\hline$\infty$ & or & $\vec{\Xi}$ & & $\stackrel{\Xi}{\Xi}$ & & & & & $\vec{\Xi}$ & $\begin{array}{l}\stackrel{*}{0} \\
\sigma\end{array}$ \\
\hline$\vec{v}$ & or & & & N) & \begin{tabular}{l}
0 \\
+ \\
\multirow{*}{*}{}
\end{tabular} & & $\overrightarrow{\mathbb{E}}$ & & $\stackrel{\vec{E}}{\mathbb{E}}$ & $\stackrel{\text { Q }}{\stackrel{\Delta}{v}}$ \\
\hline 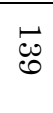 & $\stackrel{0}{0}$ & or & or & $\infty$ & $\sigma$ & or & $v$ & or & $\checkmark$ & 光苞 \\
\hline
\end{tabular}

Figures in parenthesis show where shares held by permitted transferees also convert.

*Two companies had both provisions for conversion of shares upon holder death and collapse of the dual-class structure upon founder death. They are counted in the former group for purposes of totals. 
D. Transfer Sunsets

\begin{tabular}{|c|c|c|c|c|c|c|c|c|c|c|c|}
\hline 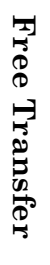 & $\begin{array}{l}Z \\
0 \\
0 \\
0 \\
0 \\
0 \\
0 \\
0 \\
0 \\
0 \\
0 \\
0\end{array}$ & 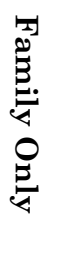 & 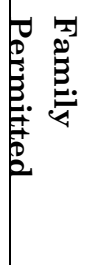 & 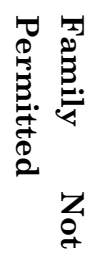 & 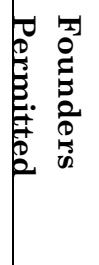 & 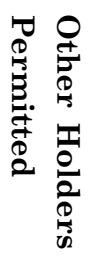 & 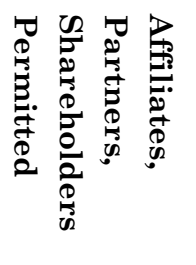 & 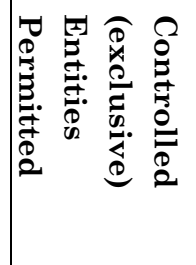 & 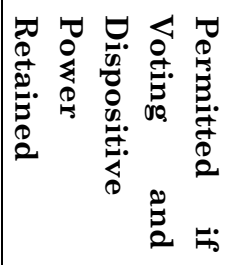 & 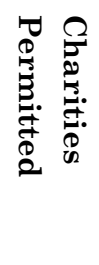 & 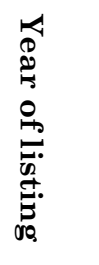 \\
\hline ๕ొ & $N$ & ๖ & 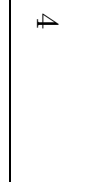 & & & $\vdash$ & $N$ & 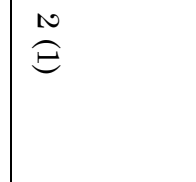 & & $\omega$ & 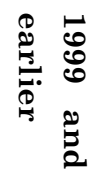 \\
\hline & & & & & & & & & & & 苂 \\
\hline- & & & & & & & & & & & $\stackrel{N}{\stackrel{0}{0}}$ \\
\hline & & $N$ & 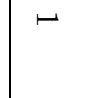 & & & & & $\vdash$ & $\vdash$ & $\vdash$ & 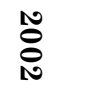 \\
\hline$\leftarrow$ & & - & 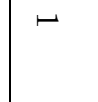 & & & 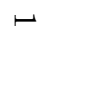 & $\vdash$ & & & $\vdash$ & :ّ̊ి \\
\hline$N$ & & & & $\vdash$ & $N$ & & $\vdash$ & $\vdash$ & $\vdash$ & & $\stackrel{ }{\circ}$ \\
\hline N & & $\vdash$ & $\vdash$ & & & & $\vdash$ & $\vdash$ & & $\vdash$ & 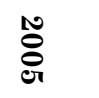 \\
\hline
\end{tabular}




\begin{tabular}{|c|c|c|c|c|c|c|c|c|c|c|c|}
\hline & & & & $r$ & & 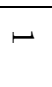 & & & & & $\stackrel{10}{0}$ \\
\hline- & $r$ & & & & & & & & & & $\stackrel{乛}{0}$ \\
\hline$N$ & & & & & & & & & & & $\stackrel{N}{ }$ \\
\hline & & $r$ & & & & & & & & & $\stackrel{1}{8}$ \\
\hline$N$ & & $\omega$ & $r$ & & & & & & $r$ & & $\stackrel{ }{\varrho}$ \\
\hline N & & & & $\omega$ & $r$ & $r$ & & & $\omega$ & & ㄴ \\
\hline & & 10 & $r$ & $\omega$ & $r$ & & & $\stackrel{N}{\Theta}$ & $\omega$ & $r$ & 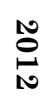 \\
\hline$r$ & & No & $r$ & & & & & $r$ & $\omega$ & & $\stackrel{\text { Q }}{0}$ \\
\hline$r$ & $r$ & & 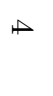 & $r$ & & & $\omega$ & N & No & $r$ & $\underset{\not}{\stackrel{D}{0}}$ \\
\hline
\end{tabular}


No. 3:852]

SUNRISE, SUNSET

949

\begin{tabular}{|c|c|c|c|c|c|c|c|c|c|c|c|}
\hline$r$ & & - & N & $\checkmark$ & $r$ & $\mapsto$ & $r$ & $\vec{\Xi}$ & $\infty$ & $r$ & $\stackrel{\text { }}{0}$ \\
\hline$r$ & $r$ & & N & $\omega$ & $r$ & 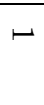 & $N$ & & $\omega$ & & $\begin{array}{l}\stackrel{N}{0} \\
\sigma\end{array}$ \\
\hline$r$ & & $N$ & $\Xi$ & $\mapsto$ & $N$ & & $N$ & & $\checkmark$ & $N$ & $\stackrel{゚}{\varrho}$ \\
\hline$\infty$ & or & $\mathfrak{\mho}$ & ¿̊ & 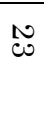 & $\infty$ & 0 & $\overleftrightarrow{\omega}$ & $\stackrel{\vec{E}}{\vec{E}}$ & $\underset{N}{\mathscr{W}}$ & $\Xi$ & $\begin{array}{l}\overrightarrow{0} \\
\stackrel{D}{\oplus}\end{array}$ \\
\hline
\end{tabular}


E. Companies Listing Both High- and Low-Vote Shares

Bio-Rad Laboratories, Inc.

Brown-Forman, Inc.

CBS Corp.

Constellation Brands, Inc.

Discovery Communications, Inc.

Forest City Enterprises, Inc.

HEICO Corp.

Hubbell, Inc.

John Wiley \& Sons, Inc.

Molson Coors Brewing Co.

Molex, Inc.

News Corp

Twenty-First Century Fox, Inc.

Viacom, Inc.

Watsco, Inc.

F. Dual-Class Data Set Companies with Time-Based Sunsets

ACM Research, Inc., listed 2017 (five years)

Altair Engineering, Inc., listed 2017 (twelve years)

Alteryx, Inc., listed 2017 (ten years)

Apptio, Inc., listed 2016 (seven years)

Castlight Health, Inc., listed 2014 (ten years)

Fitbit, Inc., listed 2015 (twelve years)

Groupon, Inc., listed 2011 (five years)

Hamilton Lane, Inc., listed 2017 (ten years)

Ironwood Pharmaceuticals, Inc., listed 2010 (eight or twenty-eight years)

Kayak Software Corporation, listed 2012 (seven years)

MaxLinear, Inc., listed 2010 (seven years)

MINDBODY, Inc., listed 2015 (seven years)

MuleSoft, Inc., listed 2017 (five years)

Nutanix, Inc., listed 2016 (seventeen years)

Okta, Inc., listed 2017 (ten years)

Pure Storage, Inc., listed 2015 (ten years)

Re/Max Holdings, Inc., listed 2013 (five years) 
RingCentral, Inc., listed 2015 (seven years)

Rockwell Automation, Inc., listed 1987 (ten years)

Stitch Fix, Inc., listed 2017 (10 years)

Texas Roadhouse, Inc., listed 2004 (five years)

Twilio, Inc., listed 2016 (seven years)

Veeva Systems, Inc., listed 2013 (ten years)

Workday, Inc., listed 2012 (twenty years)

Yelp, Inc., listed 2012 (seven years)

G. Dual-Class Data Set Companies with Both Death and Incapacity Sunset Triggers

Altair Engineering, Inc.

Apptio, Inc.

Bandwidth, Inc.

Blue Apron Holdings, Inc.

Box, Inc.

Fairway Group Holdings Corp.

Groupon, Inc.

Laureate Education, Inc.

LinkedIn Corp.

MINDBODY, Inc.

Moelis \& Company

MuleSoft, Inc.

Okta, Inc.

RingCentral, Inc.

RMR Group, Inc.

Square, Inc.

Texas Roadhouse, Inc.

Tilly's Inc.

Twilio, Inc.

Under Armour, Inc.

Veeva Systems, Inc.

Workday, Inc.

Yelp, Inc.

Zillow, Inc.

zulily, Inc.

Zynga, Inc. 